\title{
Production and Secretion of Recombinant Human Fibrinogen by the Transgenic Murine Mammary Gland
}

\author{
Stephen P. Butler
}

Thesis submitted to the faculty of the Virginia Polytechnic Institute and State University in partial fulfillment of the requirements for the degree of

\section{MASTER OF SCIENCE \\ IN \\ DAIRY SCIENCE}

\author{
F.C. Gwazdauskas, Chair \\ R.M. Akers \\ W.H. Velander \\ E.A. Wong
}

May 19, 1997

Blacksburg, Virginia

Keywords: Fibrinogen, Transgenic, Mammary Gland, Whey Acidic Protein 


\begin{abstract}
The mammary gland of lactating transgenic animals has several advantages for production of heterologous proteins including a high cell density that results in high concentrations of secreted protein and the ability to perform several types of post-translational modifications. Transgenes were constructed from the $4.1 \mathrm{kbp}$ murine Whey Acidic Protein promoter (mWAP) and the three cDNAs coding for the $A \alpha, B \beta$ and $\gamma$ fibrinogen chains to evaluate the requirements of the transgenic murine mammary gland for high level secretion of fully assembled human fibrinogen. After introducing the constructs into the murine zygotes by microinjection, secretion of fully assembled fibrinogen into milk was measured at concentrations between $10 \mu \mathrm{g} / \mathrm{ml}$ to $200 \mu \mathrm{g} / \mathrm{ml}$. In one line of mice the total secretion of fibrinogen and unassembled subunits approached 700 $\mu \mathrm{g} / \mathrm{ml}$ in milk. The level of assembled fibrinogen was proportional to the lowest amount of subunit produced where both the $\mathrm{B} \beta$ and $\gamma$ chains were rate limiting. Also, the subunit complexes $\gamma_{2}, A \alpha \gamma_{2}$ and the individual subunits $A \alpha, B \beta$ and $\gamma$ were found as secretion products. This is the first time that secretion of individual $B \beta$-subunits by any cell type has been reported and suggests the organization of the secretion pathway in mammary epithelia is different from that in liver. Glycosylated forms of individual $\mathrm{B} \beta$-chain contained a complex saccharide with low mannose. Glycosylation of the $\gamma$-chain was also observed. These results suggest the 4.1 mWAP promoter can drive expression of fibrinogen cDNAs to high levels and that the amount of fully assembled fibrinogen secreted is equal to the level of the lowest expressing chain.
\end{abstract}




\section{Acknowlegements}

I would like to thank Dr. R.S Canseco for his instruction on zygote manipulations, Dr. C.G. Russel for his consultation on DNA cloning issues and his development of the WAP5fibrinogen transgenes in February of 1993, Dr. S. Lord for providing the fibrinogen cDNAs and antibodies used in this thesis, Drs. A. Subramanian and K. E. Van Cott for their development of protocols for the purification and identification of fibrinogen in transgenic mouse milk, and M. Dunlap and T. O'Sicky for technical support. Most of all, I would like to thank my parents for their moral and financial support. 


\section{Table of Contents}

Chapter 1. Introduction 1

Chapter 2. Literature Review

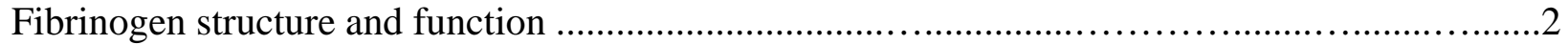

Potential uses for recombinant human fibrinogen........................................ 2

Synthesis of fibrinogen in cell culture ..................................................................4

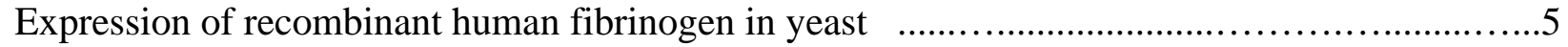

Transgenic livestock as an alternative source of recombinant fibrinogen .........................5

Expression of recombinant human fibrinogen in transgenic mice and sheep .......................8

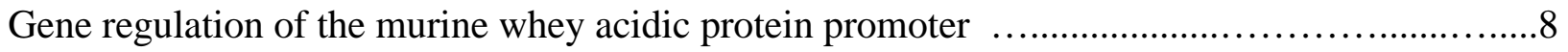

Results of the mWAP promoter in transgenic animals . .......................................... 9

Chapter 3. High Level expression of Human Fibrinogen in the Milk of Transgenic Mice Using a 4.1 Kbp Murine Whey Acidic Protein Promoter

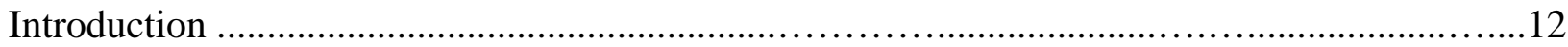

Materials and Methods

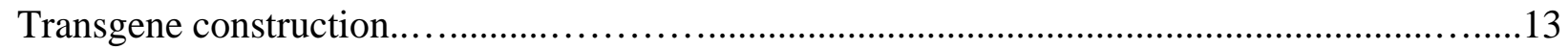

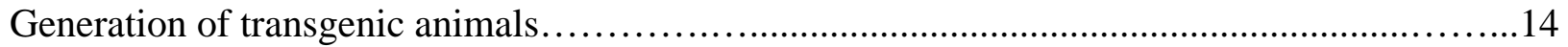

Identification of transgenic animals................................................................... 17

Isolation and measurement of mRNA.................................................................... 17

Collection and processing of mouse milk............................................................. 18

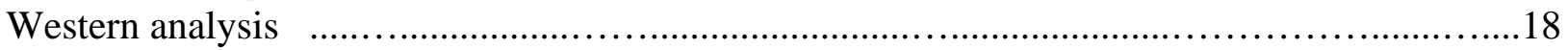

Detection of rhfib by ELISA............................................................................. 19

Results

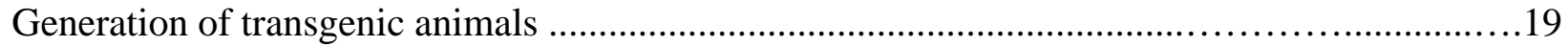

Expression of fibrinogen mRNAs .........................................................................20

Identification of assembled fibrinogen and fibrinogen chain complexes in milk................21

Glycosylation pattern of rhfib beta and gamma subunits .........................................27

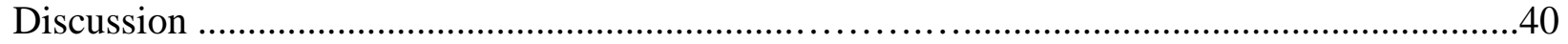

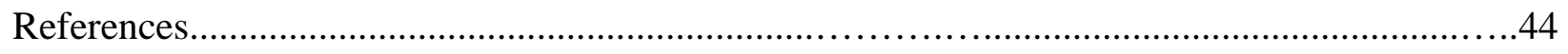

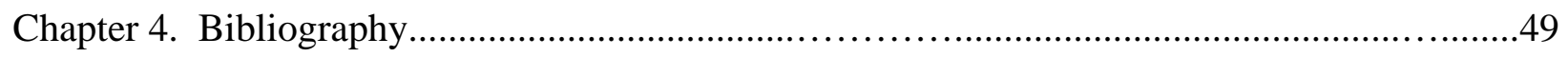

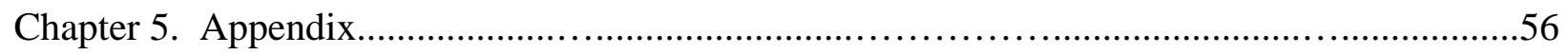

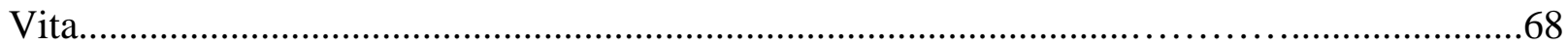




\section{List of Figures}

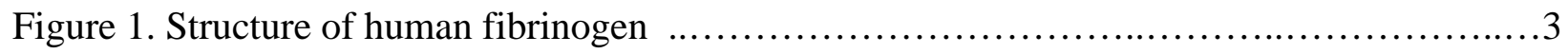

Figure 2. Proposed mechanisms for fibrinogen assembly .....................................

Figure 3. Gene schematic of the plasmid pUCWAP6 ........................................

Figure 4. Gene schematics of the transgene constructs WAP6FibA $\alpha 1$, WAP6FibB $\beta 1$,

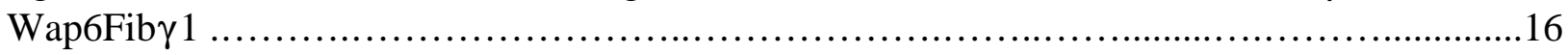

Figure 5. Southern analysis of mice containing the three constructs

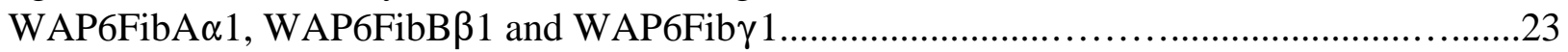

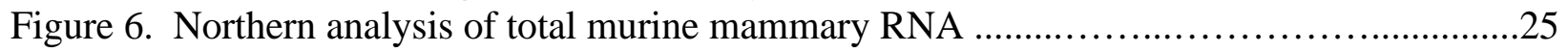

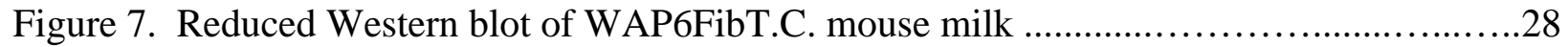

Figure 8. Nonreduced Western blot of WAP6FibT.C. mouse milk ..................................29

Figure 9. Nonreduced Western analysis for A $\alpha$-chain of selected WAP6FibT.C.

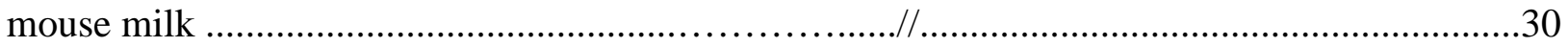

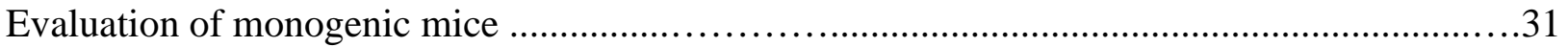

Figure 10. Nonreduced Western analysis for B $\beta$-chain of selected WAP6FibT.C.

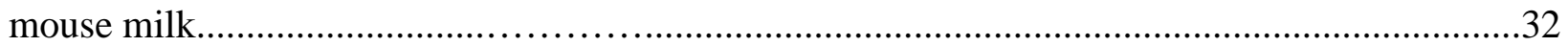

Figure 11. Nonreduced Western analysis for $\gamma$-chain of selected WAP6FibT.C.

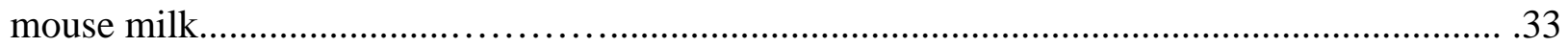

Figure 12. Deglycosylation of human and recombinant fibrinogen $B \beta$-chain .......................34

Figure 13. Deglycosylation of human and recombinant fibrinogen $\gamma$-chain ........................35

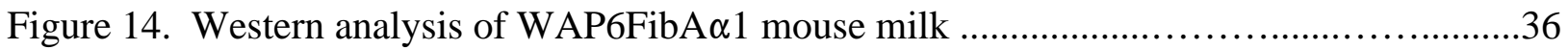

Figure 15. Western analysis of WAP6FibB $\beta 1$ single chain milk.........................................39 


\section{List of Tables}

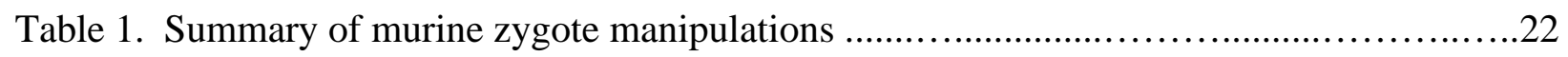

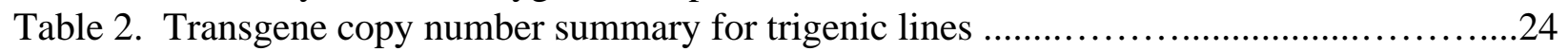

Table 3. Expression of mRNA and subunit concentration of select mice..........................26

Table 4. Copy number determination for WAP6FibA $\alpha 1$, WAP6FibB $\beta 1$ and

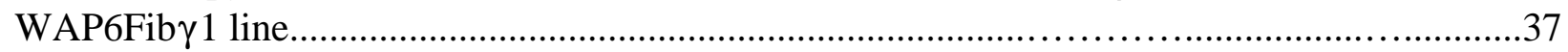

Table 5. Summary of mRNA expression from expressing WAP6FibB $\beta 1$ lines..................38

Table 6. Summary of transgene transmission from founder animals......................................57

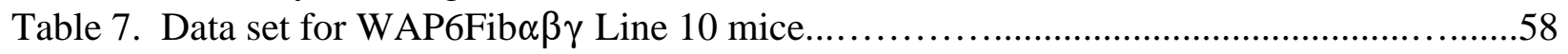

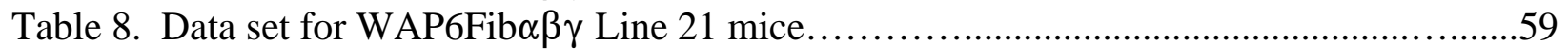

Table 9. Data set for WAP6Fib $\alpha \beta \gamma$ Line 37 mice..............................................................60

Table 10. Data set for WAP6FibA $\alpha 1$ Line 43 mice............................................................61

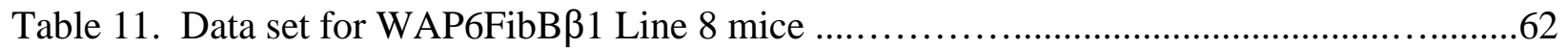

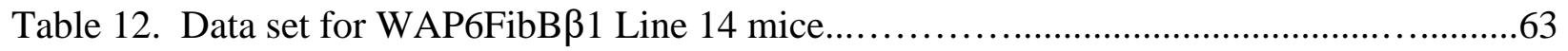

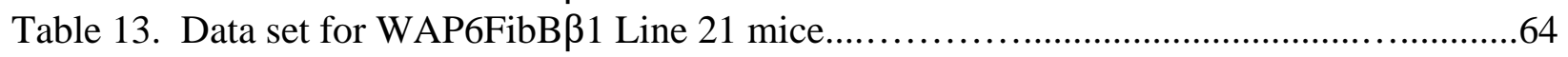

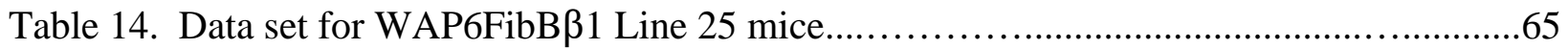

Table 15. Data set for WAP6FibB $\beta 1$ Line 28 mice..........................................................66

Table 16. Data set for WAP6Fiby 1 Line 1 and Line 6 mice...............................................67 


\section{Chapter 1 \\ Introduction}

As modern society nears the dawn of the $21^{\text {st }}$ century many advancements in science and technology have evolved which will play an important role in the next millennium. One of these new scientific applications is the ability to manipulate human DNA and incorporate it into the genome of a different species. The possibilities for this new technology seem endless and have been the subject matter for several fiction books and movies. Some non-fiction areas in this science that are currently being pursued include: altering the tissue composition of animal organs for possible transplantation into humans and modifying the mammary gland of livestock to secrete valuable human therapeutics into milk. The latter topic is the focus of this thesis, specifically, the production and secretion of recombinant human fibrinogen (rhfib) by the mammary gland of a transgenic animal.

Recent advancements in purification of fibrinogen (fib) from human blood have allowed for the identification of several potential uses for this dynamic protein. They include: use as a tissue sealant during delicate surgical operations, a wound applicant to stop bleeding after trauma and as a carrier matrix for antibiotics, growth factors and cancer therapeutics. The current blood supply available for plasma fractionation can support the initial material needs for these applications, but there is reluctance in the medical field to use blood derived products for fear of transmitting known and unknown pathogens. Steps can be taken to remove contaminants, but the purification and validation cost would be very expensive. Thus, an alternate source for fibrinogen is required that is both economical and pathogen-free for common acceptance and wide spread use in these new applications. One potential pathogen-free source of human fibrinogen (hfib) is in the milk of livestock which have been genetically altered. By taking the three genes coding for fibrinogen and placing them under the control of a mammary specific promoter, it may be possible to secrete fibrinogen in milk at a level that is economically viable.

The objective of this study was to evaluate the gene regulation requirements of the mammary gland for producing each fibrinogen subunit in order to optimize full chain assembly and secretion into milk. Topics assessed include the efficiency of expressing the fib chain cDNAs by a $4.1 \mathrm{kbp}$ murine Whey Acidic Protein promoter (mWAP), the relationship between transgene copy number and the level/ratio of the three mRNAs produced. Additional areas of assessment include the influence of mRNA levels on secretion of subunit, subunit complexes, assembled fibrinogen secretion, and the glycosylation state of both the $\mathrm{B} \beta$ and $\gamma$ subunits of secreted, assembled fibrinogen. 


\section{Chapter 2 \\ Literature Review}

\section{Fibrinogen structure and function}

Fibrinogen is a complex plasma glycoprotein that participates in the blood coagulation cascade. It is synthesized in the liver as a dimetric molecule comprised of two subunits linked by three disulfide bonds, each containing three polypeptide chains for a combined molecular weight of $340 \mathrm{KDa}$, Figure 1. The three polypeptides A $\alpha(66 \mathrm{KDa}), \mathrm{B} \beta(54 \mathrm{KDa})$, and $\gamma(48 \mathrm{KDa})$ are linked by disulfide bridges to form a coiled coil of $\alpha$-helices (Doolittle, 1984). N-linked polysaccharides are present on the $\mathrm{B} \beta$ and $\gamma$ chains of both half molecules and glycosylation of these chains are required for fibrin polymerization. When fibrinogen is converted to fibrin by thrombin, release of two fibrino peptides (A and B) of 16 and 14 residues, respectively, occurs from the $\mathrm{N}$-termini of $\mathrm{A} \alpha$ and $B \beta$ chains. This cleavage allows for charge associations between fibrin molecules resulting in formation of a "soft" fibrin clot. After clot formation, activated Factor XIII (FXIII) cross-links the gamma chains of adjacent fibrin molecules to form a "hard" fibrin clot. In normal healthly adults, plasma levels for fibrinogen range from 1 to $3 \mathrm{~g} / \mathrm{l}$.

\section{Potential uses for recombinant human fibrinogen}

Many applications for fibrin sealant (FS) have been developed over the past two decades due to the increased availability of human fibrinogen derived from cryoprecipitation processing of human plasma (Alving et al., 1995). After removal of the cryoprecipitant from chilled plasma, the 'cryopoor' plasma is used as a feedstream for Cohn fractionation. In addition to use as an hemostatic agent, new FS-applications include carrier matrix applications for the delivery of drugs and biologics (Alving et al., 1995; Greco et al., 1991; MacPhee et al., 1996a; MacPhee et al., 1996b; Lasa et al., 1996). The increase in diversity for FS-based technologies has grown to the extent that the low yields of hfib produced by cryoprecipitation cannot meet projected clinical demands. Chromatographic processing would increase yields and the viral safety of plasmaderived hfib and other proteins (Velander et al., 1990). However, the re-validation of Cohn plasma fractionation products which are downstream to any new hfib processing step would be costly. In addition, while the risk of disease transmission from today's human plasma derived fibrin sealant products has been greatly reduced by modern viral inactivation methods, further increases in safety are being pursued in the advent of contamination by previously unknown pathogens (Alving et al., 1995; Velander et al., 1990; Dodd, 1994). Thus, there is considerable economic incentive to develop recombinant versions of hfib as well as other plasma-derived proteins which would be specific-pathogen-free (SPF) and cost effectively abundant (Lubon et al., 1996; Velander et al., 1996). In addition, since FS-technologies also use significant amounts of 


\section{Human Fibrinogen}
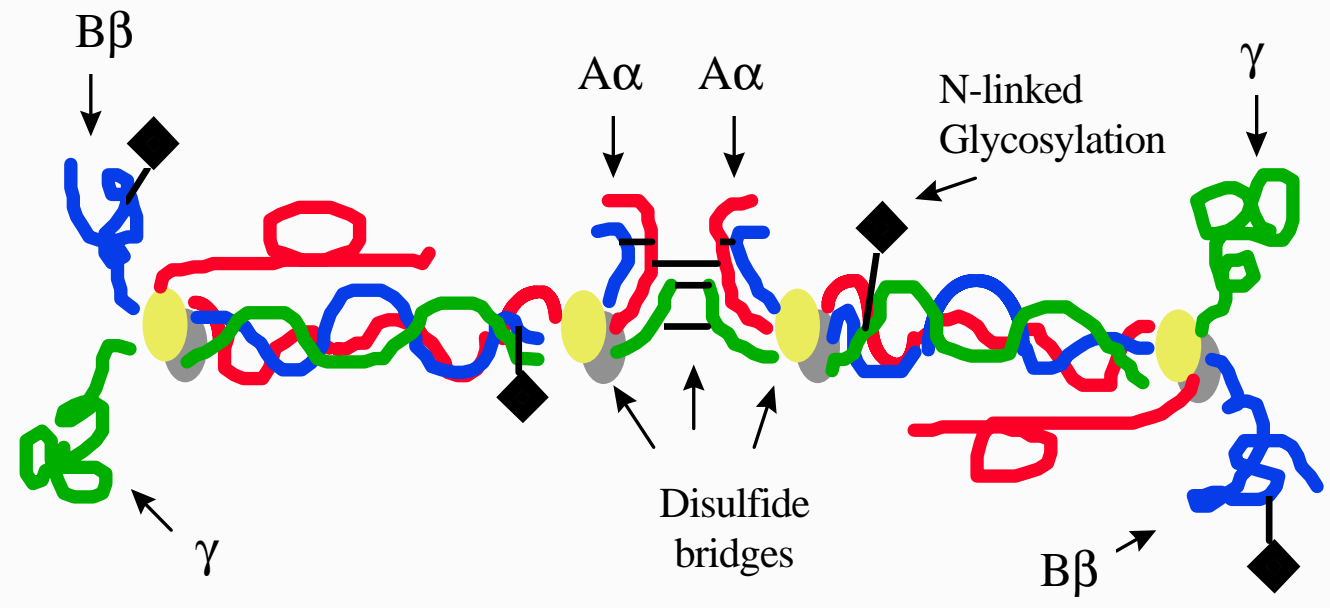

Figure 1. Structure of Human Fibrinogen

Human fibrinogen is comprised of six polypeptide chains; 2 of $A \alpha, 2$ of $B \beta$ and 2 of $\gamma$, linked together by disulfide bridges. N-linked glycosylation occurs on each $\mathrm{B} \beta$ and $\gamma$ chain. 
thrombin, a SPF source of recombinant human thrombin is also desirable. Fortunately, recombinant vitamin-K-dependent proteins have been produced at high levels in the milk of transgenic pigs (Velander et al., 1996; Morcol et al., 1994) and thus could serve as a SPF source. for recombinant prothrombin. The utility of FS-based technologies lies in the natural biological properties of fibrin derived from hfib (Alving et al., 1995; Greco et al., 1991). These properties include: biological compatibility, rapid polymerization, tensile strength and tissue-adhesiveness. Fibrin also serves as a key structural element involved in signaling the organized deposition of new tissue during healing. Since fibrin is naturally degraded in a manner controlled by the local physiology in response to healing, its longevity in vivo is inherently scaled to the needs of localized drug delivery to damaged or diseased tissue. For example, chemotherapies (MacPhee et al., 1996a ), antibiotics ( Greco et al., 1991; MacPhee et al., 1996b), growth factors and osteoinducers (Lasa et al., 1996) are some of the agents which can be easily permeated in FS applications through premixing with fibrinogen and thrombin FS-precursor reagents. The molecular transport within the FS matrix is naturally suited for slow release of these agents in the aqueous environment of the healing wound. For example, steady release of even small amounts of antibiotics from FS can occur over a two week delivery span in dilute, in vitro aqueous conditions (MacPhee et al., 1996b).

In summary, all of the above characteristics of a functional FS help to define the molecular characteristics that rhfib should possess. Optimally, rhfib should resemble hfib with respect to reaction kinetics of thrombin induced polymerization and $\gamma$-chain cross-linking by Factor XIII. Also, rhfib-derived fibrin should resemble hfib-derived fibrin with respect to adhesive and tensile strength, kinetics of natural fibrinolysis, intra-fibrin molecular transport properties for drug and biologic delivery applications, and immunogenicity (Alving et al., 1995).

\section{Synthesis of fibrinogen in cell culture}

The cDNA sequences coding for each fibrinogen chain have been cloned (Rixon et al., 1983; Chung et al., 1983a; 1983b), and the assembly phenomena has been extensively studied in the production of rhfib by mammalian cells in culture (Yu et al., 1984; Otto et al., 1987; Danishefsky et al., 1990; Roy et al., 1990; Roy et al., 1991; Hartwig and Danishefsky, 1991; Huang et al., 1993; Roy et al., 1994; Huang et al., 1996). The mechanism for assembly apparently requires a pool of precursor fibrinogen polypeptides to be retained intracellularly by chaperon proteins that are present within the endoplasmic reticulium and Golgi secretory apparatus. The cDNAs for human fibrinogen have been separately and co-expressed in transfected monkey kidney fibroblast (COS-1; Danishefsky et al., 1990; Roy et al., 1991; Hartwig and Danishefsky, 1991), baby hamster kidney (BHK; Huang et al., 1993; Huang et al., 
1996), chinese hamster ovary (CHO; Binnie et al., 1993) and Hep G2 cells (Roy et al., 1990; Roy et al., 1994). Results from these studies indicated that assembly of fibrinogen is not necessary for chain secretion. Reports of secretion of individual chains and chain complexes into media have been limited to free $A \alpha$ and $\gamma$ chains, along with the chain complexes $A \alpha \gamma_{2}, A \alpha B \beta \gamma_{2}$ and half molecules $\mathrm{A} \alpha \mathrm{B} \beta \gamma$. However, the $\mathrm{B} \beta$ chain is not secreted and appears to be the rate limiting step of fibrinogen synthesis in the rough endoplasmic reticulum (Yu et al., 1984; Roy et al., 1990). To determine if $B \beta$ chain synthesis is the rate limiting step in fibrinogen secretion, Hep G2 cells were transfected with $B \beta$ chain coding plasmids yielding a four fold increase in secretion of mature fibrinogen over control Hep G2 cells (Roy et al.,1990). Also, intracellular pools of $A \alpha$ and $\gamma$ chains were increased in response to the elevated levels of $B \beta$-chain. The regulatory mechanism for this action is currently unclear, but may involve enhanced gene transcription. Primary rat hepatocytes in cell culture transcribe their fibrinogen chain mRNAs identically and regulate them in a tightly coordinated fashion (Nesbitt and Fuller, 1991). Intracellular single chains of $A \alpha, B \beta$ and $\gamma$ were found noncovalently associated with binding protein (BiP, GRP78) with varying affinities. The postulated role for $\mathrm{BiP}$ is involvement in proper assembly and/or sequestering peptide components necessary for complex proteins. The previous observations linked with determination of intracellular chain complexes has allowed for Hartwig and Danishefsky (1991) to postulate the a mechanism for fibrinogen synthesis, Figure 2A. Huang et al. (1993) has postulated a different mechanism based on intracellular products found in transfected BHK cells. It involves association of $B \beta$ or $A \alpha$ with the $\gamma$ subunit to form either $B \beta \gamma$ or $A \alpha \gamma$, then after the missing chain is added, the half molecules come together, Figure 2B.

\section{Expression of rhfib in yeast}

Secretion of functional rhfib into culture media of transformed Saccharomyces cerevisiae has been reported (Roy et al., 1995). Expression vectors were constructed using the cDNAs for each fibrinogen chain fused to the Gal-1 yeast promoter which resulted in secretion of rhfib into the medium at a concentration of $30 \mu \mathrm{g} / \mathrm{ml}$. Purified rhfib acted as a functional substrate for thrombin resulting in a fibrin clot which was capable of being cross linked by FXIII. It was also observed that both the $\mathrm{B} \beta$ and $\gamma$ chains were glycosylated. Carbohydrate analysis of secreted rhfib indicated that the glycoprotein was not of the high mannose type, indicating a mature oligosaccharide structure. However, the terminal sugar residues were not sialic acid, which is found on liver synthesized fibrinogen.

\section{Transgenic livestock as an alternative source of recombinant fibrinogen}

Estimates of annual US clinical need are now greatly in excess of the approximately $300 \mathrm{~kg}$ per 
year which can be harvested on the total of 7 million liters of human plasma in the US (Paleyanda et al., 1991). Thus, the recombinant source must be capable of economically supplying about $1000 \mathrm{~kg} / \mathrm{yr}$ in order to replace the maximum possible hfib obtainable from current plasma fractionation by cryoprecipitation. The use of the mammary gland of transgenic livestock as a bioreactor for producing rhfib is currently being evaluated in dairy livestock and pigs. While dairy cattle are the most prodigious milk producers, the goat, sheep, and pig have all demonstrated the ability to produce $\mathrm{g} / \mathrm{l}$ levels of recombinant proteins. The annual milk yields of these livestock are approximately 1000 liters per year for the goat, $500 \mathrm{l} / \mathrm{yr}$ for the sheep, and 100 to $300 \mathrm{l} / \mathrm{yr}$ for the pig. Thus, only 2000 sows would be needed to produce $1000 \mathrm{~kg} / \mathrm{yr}$ or more of rhfib at a concentration of $5 \mathrm{~g} / \mathrm{l}$ in milk. Using the transgenic mammary gland for production of rhfib has several necessary requirements. First, DNA constructs which use mammary pecific promoters effective for expressing cDNA, minigene, or genomic fibrinogen coding sequences must be formulated. These constructs need to be introduced into embryonic cells, typically using microinjection into the pronucleus of zygotes. Second, the cointegration of constructs containing each of the $\alpha, \beta$, and $\gamma$ encoding sequences for hfib into a transcriptionally responsive chromosomal domain is needed. In some instances, the cointegration of an additional genomic sequence for a milk protein can be used to artificially create a transcriptionally active chromosomal domain for mammary tissue specific expression (Clark et al., 1992; reviewed in Lubon et al., 1996). For the purposes of pharmaceutical production at large-scale, a single cointegration site and associated transgene copy number in that locus is desirable for the facile establishment of a phenotypical and genotypical stable lineage (Van Cott et al., 1997). Mosaicism and multiple integration sites frequently occur in founder animals and this complicates analysis of founder animals (Velander et al., 1992b). Thus, phenotype and genotype can not be reliably defined in transgenic animals until successive generations of offspring obtained from outbreeding with nontransgenic animals are analyzed (Van Cott et al., 1997; Velander et al., 1992b; Carver et al., 1993). A production lineage must be shown to reproducibly secrete the recombinant protein at a level and functionality which can be associated with a given trans-genotypic signature.

The evaluation of mammary tissue specific promoters which are suitable for use both in conventional dairy livestock and the pig is still ongoing. However, several promoters have been demonstrated to be useful for the expression of complex human recombinant proteins in the milk of pigs and sheep (Lubon et al., 1996 and references in). These promoters have behaved differently across animal species. The most stable expression patterns have been observed throughout multiple lactations in transgenic animals that contain a single integration locus (Van Cott et al., 1997; Carver et al., 1993). In most cases, the biosynthesis of both the recombinant and endogenous proteins has been compatible with normal mammary gland physiology. However, some changes in endogenous milk protein composition have occurred as a result of 


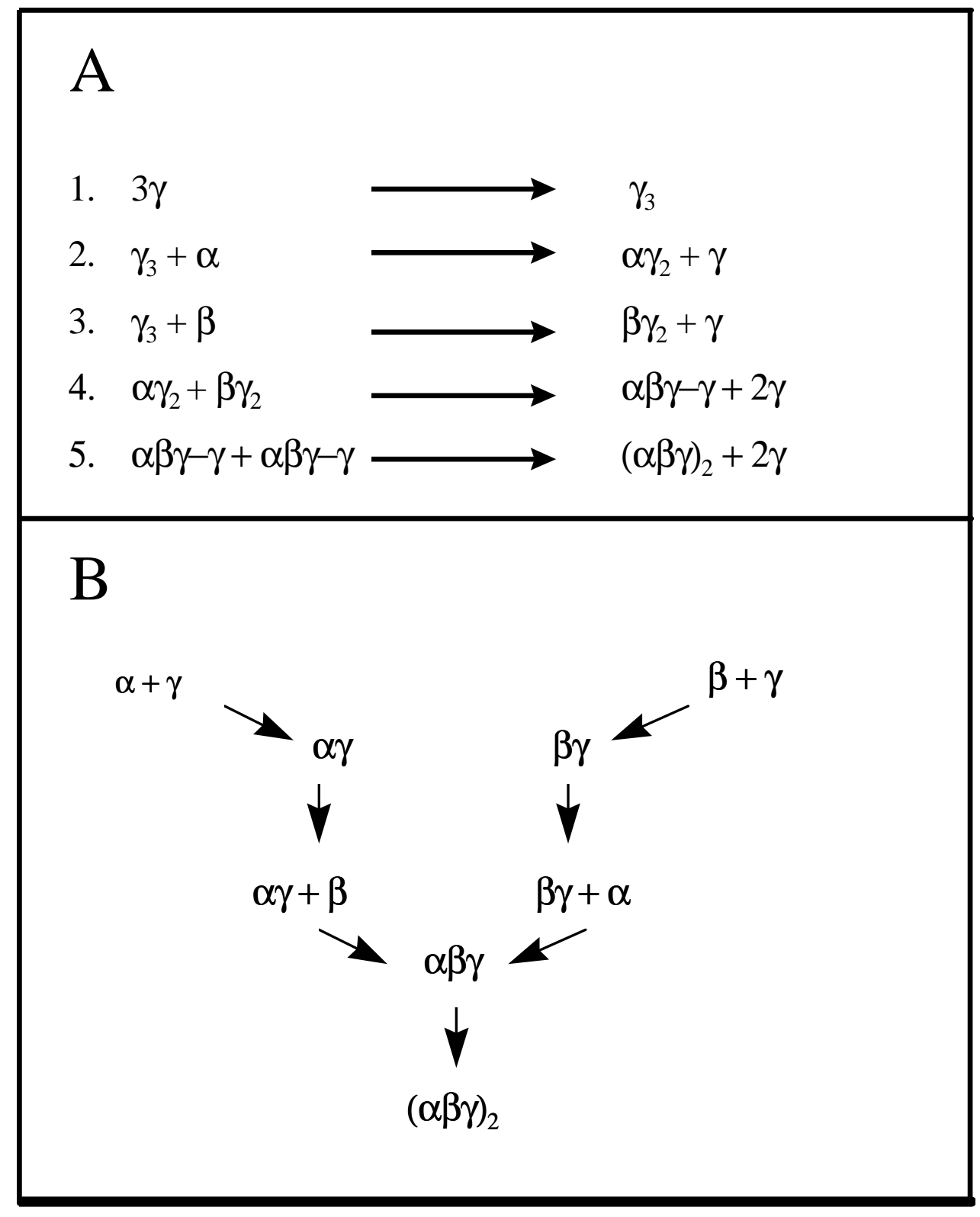

Figure 2. Proposed Mechanisms for Fibrinogen Assembly

Part A, mechanism proposed by Hartwig and Danishefsky, (1991). Part B, mechanism proposed by Huang et al., (1993). $\alpha$-fibrinogen A $\alpha$ chain, $\beta$ fibrinogen $B \beta$ chain, $\gamma$ - fibrinogen $\gamma$ chain. 
high level expression of recombinant proteins by the mammary gland (McClenaghan et al., 1995). The challenges to post-translational modification (PTM) and secretory processing presented by synthesizing multiple recombinant proteins at high levels in milk have not yet been thoroughly evaluated. For example, the trimeric assembly of separate polypeptides has been demonstrated in the production of recombinant human collagen by the mammary gland of transgenic mice (Toman et al., 1997). However, limitations in the $\beta$-prolyl-hydroxylation of the nascent collagen polypeptides, which is necessary for biological activity, has not been evaluated. Thus, the coordinated expression, post-translational modification and assembly of hexameric fibrinogen from mono-, di- and trimeric intermediates throughout a selected period during lactation represents a unique challenge for synthesis of a complex recombinant protein by the transgenic mammary gland.

\section{Expression of rhfib in transgenic mice and sheep}

Constructs were developed using only the coding portion of the genomic sequences for each fibrinogen chain inserted between the $4.2 \mathrm{kbp}$ ovine beta lactoglobulin promoter (oBLG) and its associated $2.5 \mathrm{kbp} \mathrm{3'}$ untranslated region (UTR). These constructs were then mixed in equimolar concentrations and injected into pronuclear phase murine (Prunkard et al., 1996) or ovine zygotes (Cottingham et al., 1997). Eighty five percent of the transgenic mice produced carried all three constructs with approximately equal copy numbers of each. The sum of rhfib subunits secreted into milk across established lines varied from 30 to $2000 \mu \mathrm{g} / \mathrm{ml}$ with 10 to $100 \%$ of the fibrinogen chains being assembled into the hexamer. Purified fibrinogen was a substrate for both thrombin and FXIII. Pronuclear microinjection of sheep zygotes using the oBLG-hfib genomic constructs resulted in the generation of 9 founder animals. Expression data from four ewes have been reported, where 3 animals contained the $A \alpha-, B \beta$-, and $\gamma$-transgenes in their genome. A fourth animal contained only genes for the $\mathrm{B} \beta$ and $\gamma$ chains. Upon hormone induced lactation at 4 months of age, milk from two of the trigenic animals contained fib subunits at a concentration of $0.5 \mathrm{~g} / \mathrm{l}$ and a third ewe produced about $5 \mathrm{~g} / \mathrm{l}$. Purified material from the highest expressing ewe was subjected to amino terminal analysis before and after thrombin cleavage resulting in the expected sequences for all three chains. SDS-PAGE analysis under reducing conditions demonstrated that, similar to the mice, sheep derived recombinant fibrinogen can undergo cross-linking to form $\gamma-\gamma$ dimers after dual treatment by human thrombin and factor XIII.

Gene regulation of the murine whey acidic protein promoter

Murine Whey Acidic Protein (mWAP) is a 14.0 KDa cysteine rich protein which comprises the 
major whey protein in rat, rabbit, and mouse milk (Hennighausen and Sippel, 1982). The function of mWAP in milk is currently unknown, but it has structural similarities to neurophysins, which transport oxytocin-like nonapeptides. The genomic sequences for WAP have been cloned (Campbell et al., 1984) and it has been determined that the complete peptide is coded for in four exons. Regulation of WAP mRNA in the mammary gland is modulated by the classical lactogenic hormones insulin, glucocorticoids and prolactin (Hobbs et al., 1982). The level of mWAP mRNA remains low during early gestation with a significant increase around day 15 in the rat. After parturition, mRNA levels increase linearly over the course of lactation. During late lactation a 100 fold increase in mRNA is observed compared to day 15 gestation levels.

The cloning of the $2.5 \mathrm{kbp}$ mWAP promoter has allowed for identification of important regulatory sequences. Mobility shift and exonuclease protection assays have determined the presences of binding sites for Stat 5 (involved in the prolactin response), glucocorticoid receptor (GR) complex and other factors necessary for transcription in the proximal promoter region (Watson et al., 1991; Welte et al., 1993; Lubon and Hennighausen, 1987; McKnight et al., 1995). Deletional analysis of the promoter in transfected HC11 cells has determined two regions between -2500 to -1500 and -450 to -1 that contain hormone response elements (Doppler et al., 1991). Further deletional analysis of the -219 to -1 segment identified an essential hormone induced enhancer region at -195 and a repressor region between -219 and -195 (Mink et al., 1992). The hormone response regions appear to contain Stat 5 binding sequences in close proximity to secondary GR recognition sequences. A postulated mechanism for hormone response involves a GR complex recognizing its sequence causing dissociation of nucleosomes from a localized region of chromatin, thus allowing Stat 5 to bind and enhance transcription.

A longer segment of the mWAP promoter was cloned and sequenced representing $4.1 \mathrm{kbp}$ upstream from the transcription initiation site (Paleyanda et al., 1994). Upon comparison of the $4.1 \mathrm{kbp}$ fragment derived from the C57/6 genomic library and the $2.5 \mathrm{kbp}$ from GR strain, similarities and differences are observed. The sequences share a high homology between -1 and 1500 , then diverge greatly further upstream. Due to the recent cloning of the $4.1 \mathrm{kbp}$ fragment, identification of transcription factor binding sites and deletional analysis either in vitro or in vivo have not been performed. Sequence screening for hormone response elements determined potential sites at $-2440,-2120,-1257,-647,-563$, and 130 of the promoter region. Due to the high homology between both promoters in the first $-1500 \mathrm{bp}$, it is likely that previous work with the $2.5 \mathrm{kbp}$ promoter in the proximal region also applies to this promoter.

Results of the mWAP promoter in transgenic animals 
The $2.5 \mathrm{kbp}$ promoter has been used to drive expression of a variety of genes in transgenic animals (Burdon et al., 1991; Pittus et al., 1988; Reddy et al., 1991; Velander et al., 1992a, 1992b; Tomasetto et al., 1989). Initial work with this promoter involved constructs using cDNA coding regions that lacked milk protein 3' untranslated regions (UTR's). Expression of the transgenes in mice with this type of construct design was low but detectable (Pittus et al., 1988; Reddy et al., 1991). RNA analysis of various tissues in transgenic mice expressing tissue Plasminogen Activator has shown that the transgene was expressed in a tissue-specific manner with low level expression in the salivary gland and kidney in certain lines (Pittus et al., 1988). To determine the level of transcription possible with this promoter, transgenic mice containing the entire genomic clone of mWAP were produced (Burdon et al., 1991). The clone contained sequences for the $2.5 \mathrm{kbp}$ promoter, intron, exon and 3' UTR segments. Results of mRNA expression varied from $3 \%$ to $54 \%$ of endogenous levels and expression was dependent upon the site of integration and copy numbers present at that locus. Some lines expressed the transgene similar to the endogenous mWAP, while in others it turned on earlier during pregnancy, turned off during lactation or had a heightened response to glucocorticoid. It was postulated that the clone contained some but not all regulatory elements necessary for correct expression. Due to conservation of 3' UTRs between milk protein genes (Dale et al., 1992) and the potentially high expression of the full clone, several constructs were developed using cDNAs inserted into the first exon of the clone (Tomasetto et al., 1989; Velander et al., 1992a; Jhappan et al., 1993). Expression of protein from these constructs was in the 5 to $30 \mu \mathrm{g} / \mathrm{ml} \mathrm{milk} \mathrm{range.} \mathrm{In} \mathrm{an} \mathrm{effort} \mathrm{to}$ raise the expression of Protein $\mathrm{C}$ in milk, a new construct (WAPPC3) was designed that deleted the poly A tail of the Protein C cDNA and the coding WAP region between the transcription start site and the poly adenylation signal (Russell, 1994). Expression levels increased 50 fold over previous constructs during first lactation but decreased to low or undetectable levels during second lactation. The reason for lack of expression during second lactation is currently unknown. Constructs using the same format but containing cDNAs coding for $A \alpha, B \beta$, and $\gamma$ chains of human fibrinogen have expressed the complete polypeptide at $30 \mu \mathrm{g} / \mathrm{ml}$ levels in transgenic mouse milk over numerous lactations (unpublished observations).

Published studies involving the $4.1 \mathrm{kbp}$ mWAP promoter in transgenic animals have been limited to expression of the genomic sequence of Protein C (Drohan et al., 1994; Paleyanda et al., 1994). The recombinant protein was measured in milk at concentrations averaging 700 $\mu \mathrm{g} / \mathrm{ml}$. Inefficient peptide cleavage and glycosylation were observed at this level of expression. Expression of the transgene mRNA was mostly tissue-specific except for low expression in the salivary gland and kidney, similar to findings with the $2.5 \mathrm{kbp}$ promoter. From histological studies it was observed that gross alterations in alveolar structure did not result from high expression of protein. To evaluate the potential of using this promoter with cDNAs, a construct was developed containing the cDNA for protein $\mathrm{C}$ placed between the $4.1 \mathrm{kbp} \mathrm{mWAP}$ promoter 
and the $1.6 \mathrm{kbp}$ mWAP 3 'UTR. The concentration of protein $\mathrm{C}$ in transgenic mouse milk across several established lines was 300 to $1500 \mu \mathrm{g} / \mathrm{ml}$, suggesting that this promoter contains elements which can express cDNAs to high levels. 


\title{
Chapter 3 \\ High Level Expression of Human Fibrinogen in the Milk of Transgenic Mice Using a 4.1 Kbp Murine Whey Acidic Protein Promoter
}

\begin{abstract}
Introduction
Fibrinogen $(\mathrm{A} \alpha \beta \gamma)_{2}$ is a complex plasma glycoprotein that participates in the blood coagulation cascade. It is synthesized in the liver as a dimetric molecule that is comprised of two subunits linked by three disulfide bonds, each containing three polypeptide chains for a combined molecular weight of $340 \mathrm{KDa}$. The three polypeptides, A $\alpha$ (66 KDa), B $\beta$ (54 KDa), and $\gamma(48$ $\mathrm{KDa}$ ) are linked by disulfide rings to form a coiled coil of $\alpha$-helices (Doolittle, 1984). N-linked polysaccharides are present on the $\mathrm{B} \beta$ and $\gamma$ chains of both subunits and glycosylation of theses chains are required for fibrin polymerization by thrombin.
\end{abstract}

The cDNA sequences coding for each fibrinogen chain have been cloned (Rixon et al., 1983; Chung et al., 1983a;1983b), and the synthesis and secretion of fibrinogen has been extensively studied in cultured hepatocytes and a variety of transfected cell types (Yu et al., 1984; Otto et al., 1987; Danishefsky et al., 1990; Roy et al., 1990; Roy et al., 1991; Hartwig and Danishefsky, 1991; Huang et al., 1993; Roy et al., 1994; Huang et al., 1996). Pulse chase experiments in hepatocytes have determined that the rates of new chain synthesis for each peptide are identical (Roy et al., 1994), and newly synthesized beta chain associates rapidly with already present intracellular pools of alpha and gamma chains, suggesting beta chain incorporation in chain assembly is the rate limiting step in fibrinogen production (Yu et al., 1984). Secretion into cell culture media is not limited to fully assembled fibrinogen, but includes free chains of $A \alpha$ and $\gamma$, an $A \alpha-\gamma$ complex and $A \alpha \beta \gamma$ half molecules (Hartwig and Danishefsky, 1991; Roy et al., 1991). In contrast, secretion of $\mathrm{B} \beta$ chain alone has not been detected by any cell type and is thought to be retained and degraded when the other fibrinogen chains are not present (Danishefsky et al., 1990).

Many applications for fibrin sealant (FS) have been developed over the past two decades due to the increased availability of human fibrinogen (hfib) from cryoprecipitation processing of human plasma (Alving et al., 1995). In addition to use as an hemostatic agent, new FS-applications include carrier matrix applications for the delivery of drugs and biologics (Alving et al., 1995; Greco et al., 1991; MacPhee et al., 1996a ; MacPhee et al., 1996b; Lasa et al., 1996). The diversity for FS-based technologies has grown to the extent that the low yields of hfib produced by cryoprecipitation cannot meet projected clinical demands. There are alternate methods to increase yield, but revalidation of plasma derived product would be costly. While the risk of disease transmission from today's human plasma derived fibrin sealant products has been greatly 
reduced by modern viral inactivation methods, a potential risk, however small, does exist. Thus, there is considerable economic incentive to develop recombinant versions of hfib (rhfib) as well as other plasma-derived proteins which would be specific-pathogen-free (SPF) and cost effectively abundant (Lubon et al., 1996; Velander et al., 1996).

One potential source that can meet these requirements is the production of rhfib in the mammary gland of transgenic animals. Several plasma proteins have already been produced in transgenic animal milk by placing human coding sequences under control of milk protein promoters (for review see Lubon et al., 1996). Currently, fully assembled fibrinogen has been secreted into the milk of both mice and sheep carrying the genomic fibrinogen coding sequences linked to the ovine beta lactoglobulin (oBLG) milk protein promoter (Prunkard et al., 1996; Cottingham et al., 1997). The concentration of fibrinogen subunits in mouse milk, as determined by reduced Western analysis, varied from 30 to $2000 \mu \mathrm{g} / \mathrm{ml}$ depending upon the transgenic line studied. When all three subunits were expressed in a balanced ratio, 100\% of the subunit chains were incorporated into fully assembled fib. This indicated the necessity for proper gene regulation in order to express each chain in an equal ratio. The glycosylation status of the $\mathrm{B} \beta$ and $\gamma$ subunits was not reported, but purified rhfib was shown to undergo thrombin induced polymerization and $\gamma$-chain crosslinking by FXIII.

The objective of this study was to evaluate the gene regulation requirements of the mammary gland for producing each fibrinogen subunit, in order to optimize full chain assembly and secretion into milk. Topics assessed include the efficiency of expressing the fib chain cDNAs by a $4.1 \mathrm{kbp}$ murine whey acidic protein promoter (mWAP), the relationship between transgene copy number and the level/ratio of the three mRNAs produced. Additional areas of assessment included the influence of mRNA levels on subunit, subunit complexes, assembled fibrinogen secretion, and the glycosylation state of both the $\mathrm{B} \beta$ and $\gamma$ subunits of secreted assembled fibrinogen.

\section{Transgene Construction}

\section{Materials and Methods}

The $4.1 \mathrm{kbp}$ mWAP promoter was obtained by digestion of p227.6 ( American Red Cross, Rockville, MD) with Not I, Kpn I and Hind III with resulting fragments separated on a $0.8 \%$ agarose gel. The promoter fragment was excised from the gel and purified using a Qiagen extraction kit (Qiagen Inc. Chatsworth, Ca). The fragment containing the 3'UTR and pUC Not I+ vector was obtained by partial digestion of pUCWAP5 with Not I and a full digestion with Kpn I and was similarly purified. The resulting fragments were then ligated with T4 DNA ligase to 
make pUCWAP6 (Figure 3) (Stratagene, LaJolla, Ca) per manufacturer's instructions and the mixture used to transform E.coli JM109 cells (Stratagene) per manufacture's instructions. Plasmid containing colonies were selected and maintained on $\mathrm{Amp}^{+} \mathrm{LB}$ plates with $\mathrm{Amp}^{+}$terrific broth (TB) used for scale up harvesting. After size and restriction site verification (Not I and Not I/Kpn I digest), large scale purification was performed by Qiagen maxi resin columns. The cDNAs for cloning were obtained from Susan Lord (University of North Carolina; Chapel Hill, NC) and end modified by PCR to produce Kpn I sites directly 5' and 3' of the coding start and stop sequences, respectively. The vector pUCWAP6 was linearized with Kpn I, combined with each cDNA and ligated with T4 DNA Ligase (Stratagene). The ligation mixture was used to transform E.coli JM109 competent cells (Stratagene) with resulting colonies picked and grown in one $\mathrm{ml}$ of $\mathrm{Amp}^{+} \mathrm{TB}$ for $12 \mathrm{~h}$. One $\mu \mathrm{l}$ of broth was removed and placed in $5 \mu \mathrm{l}$ of embryo buffer (0.9\% Tween 20 and Nonidet P40, $20 \mathrm{mM}$ Tris, $\mathrm{pH} 9.0$ ) and subjected to $98^{\circ} \mathrm{C}$ for $5 \mathrm{~min}$. Twenty $\mu 1$ of PCR mixture was then added and cycled 40 times. PCR protocol and primer information is listed under Identification of Transgenic Animals. The PCR primers were designed to amplify across the promoter/cDNA junction, which allowed for detection of the correct insert orientation. Polymerase chain reaction primers used were: WAPS2/FibA $\alpha$ A1 for pUCWAP6FibA $\alpha 1$, WAPS2/FIBB $\beta A 1$ for pUCWAP6FibB $\beta 1$, and WAPS2/FIB $\gamma$ A1 for pUCWAP6Fib $\gamma 1$. DNA from PCR positive clones was isolated and subjected to restriction digestion for verification of cDNA orientation and monomer form. The following restriction endonuclease enzymes (Stratagene) were used for verification: pUCWAP6FibA $\alpha 1 /$ Pst I yielding expected fragments of 2.1, 2.4 and $5.9 \mathrm{kbp}$; pUCWAP6FibB $\beta 1 /$ BamHI yielding fragments of $750 \mathrm{bp}$ and $9.5 \mathrm{kbp}$; pUCWAP6Fib $1 /$ Pst I yielding fragments of $980 \mathrm{bp}, 3.2$ and $5.8 \mathrm{kbp}$ (Figure 4). After verification, colonies were plated and large scale purification was performed. Sequencing was across the promoter/cDNA and cDNA/ 3'UTR junctions. Plasmids were cut with Not I/Pvu I and constructs purified by ultracentrifugation through an $\mathrm{NaCl}$ step gradient $(7.5,12.5,17.5$, and 20\%) by method of Fink et al. (1991). Construct DNA was diluted to 5 or $15 \mu \mathrm{g} / \mathrm{ml}$ in TE and mixed in equal molar amounts for co-microinjection.

\section{Generation of Transgenic Animals}

Generation of transgenic mice followed the general method of Hogan et al. (1986) for embryo collection and Canseco et al. (1994) for embryo microinjection. Briefly, female CD-1 mice approximately 25-29 D of age were superovulated with intraperitoneal injections of $10 \mathrm{IU}$ Pregnant Mare's Serum Gonadotropin followed by 5 IU human Chorionic Gonadotropin (hCG) $48 \mathrm{~h}$ later and placed with males. Embryos from mated mice were collected in M2 medium $21 \mathrm{~h}$ after hCG and microinjected with 1-4 pl of DNA solution at either 15 or $5 \mu \mathrm{g} / \mathrm{ml}$. Surviving embryos were transferred to oviducts of pseudopregnant females (30-100 embryos per recipient) 


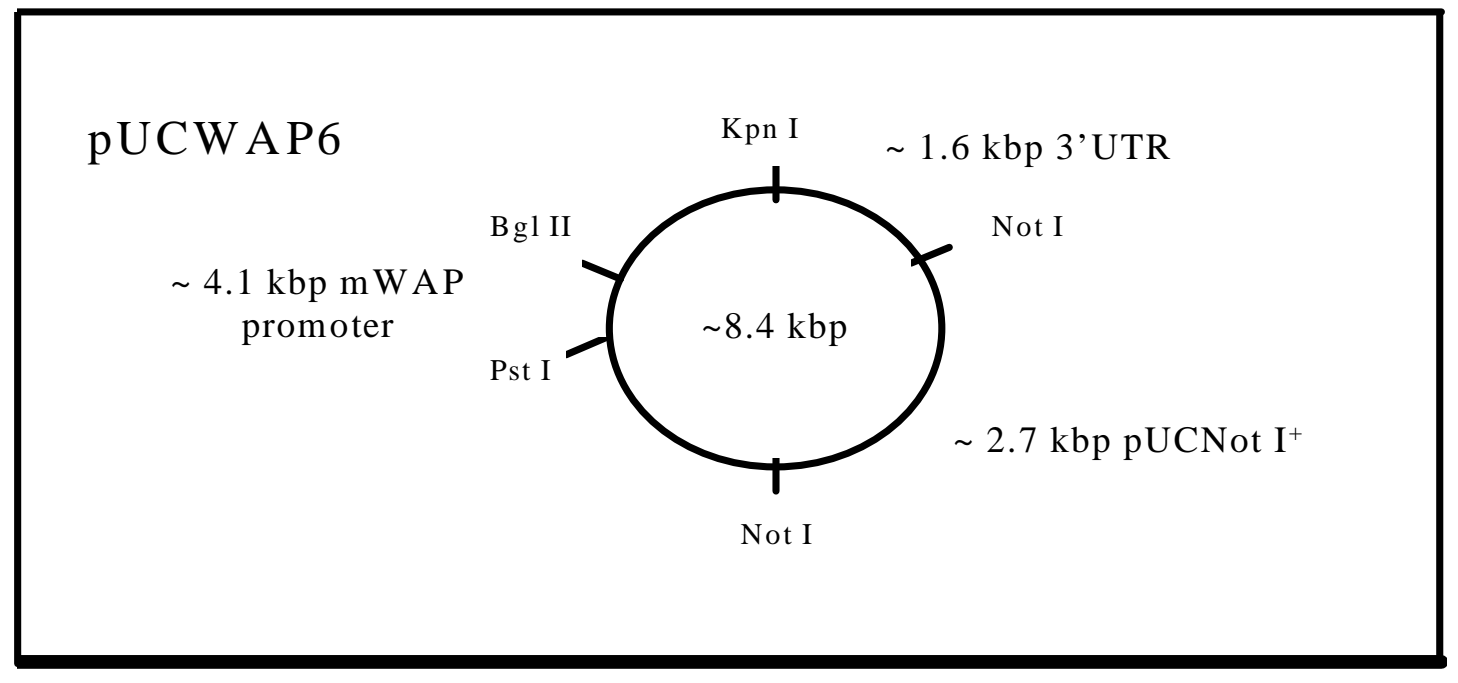

Figure 3. Gene Schematic of the Plasmid pUCWAP6. 


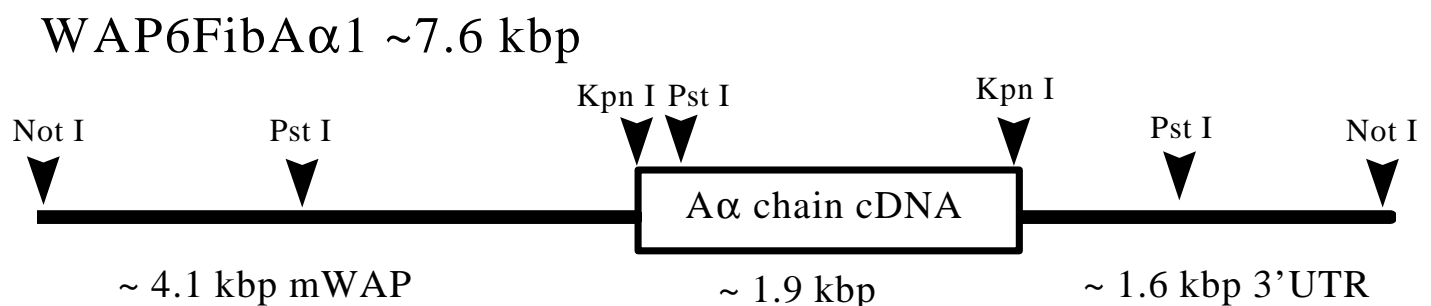

WAP6FibB $\beta 1 \sim 7.2 \mathrm{kbp}$

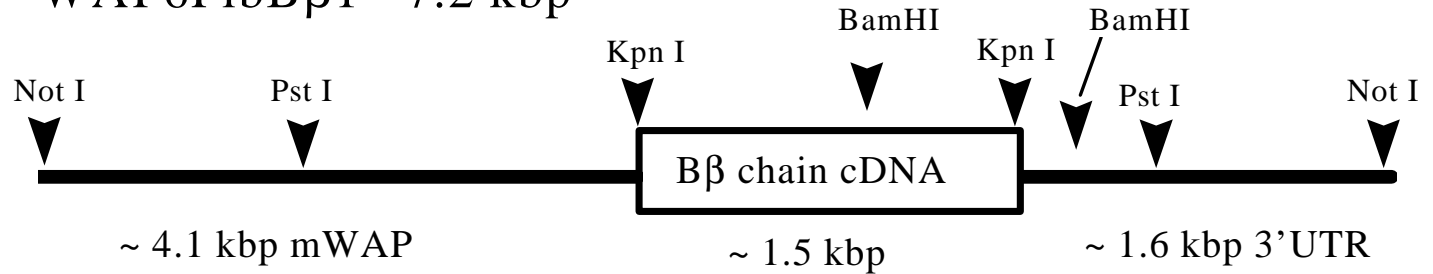

WAP6Fib $\gamma 1 \sim 7.0 \mathrm{kbp}$

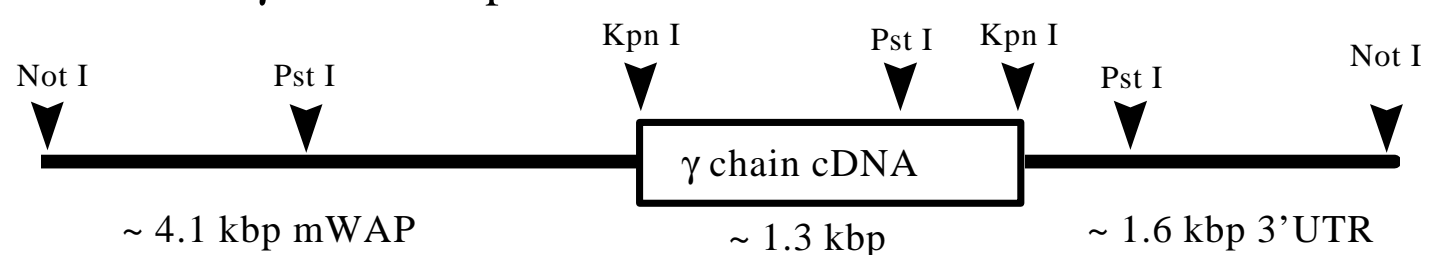

Southern Probe

Figure 4. Gene schematics of the transgene constructs WAP6FibA $\alpha 1$, WAP6FibB $\beta 1$ and WAP6Fib $\gamma 1$.

The three hybrid constructs designated WAP6FibA $\alpha 1$, WAP6FibB $\beta 1$ and WAP6Fib $\gamma 1$ were produced by modifing each fibrinogen chain cDNA with addition of Kpn I sites directly before the start and after the stop coding sequence. The cDNAs were then inserted individually into the Kpn I site of pUCWAP6. After insert verification, the constructs were exised by Not I and purified for microinjection. Some multiple cuts by the restriction enzymes listed have been omitted for clarity. 


\section{Identification of Transgenic Animals}

DNA samples were isolated from murine tail biopsies by the method of Velander et al. (1992) and subjected to PCR analysis by general method of Saiki et al. (1989). PCR protocol differed from the published protocol by placing $1 \mu \mathrm{l}$ of template DNA solution $(30 \mathrm{ng} / \mu \mathrm{l})$ in $25 \mu \mathrm{l}$ of PCR reaction mixture (1X Taq buffer, $2.5 \mu \mathrm{M}$ dNTP's, $0.5 \mu \mathrm{M}$ oligo primers, $1.5 \mathrm{mM} \mathrm{MgCl}_{2}$, and 0.625 units of Taq polymerase). Reaction parameters for alpha and gamma construct using primer screening include denaturation at $96.5^{\circ} \mathrm{C}$ for $15 \mathrm{~s}$, annealing at $57^{\circ} \mathrm{C}$ for $1 \mathrm{~min}$ and elongation at $75^{\circ} \mathrm{C}$ for $30 \mathrm{~s}$, for 40 cycles. Parameters for beta chain were similar except for an annealing temperature of $63^{\circ} \mathrm{C}$. This protocol has been experimentally verified to detect 10 copies per sample, which is sufficient to identify a highly mosaic animal. PCR primer sequences are as follows: WAPS2 5' gCAgCCggCCCTggCATC, located at -112;

FibA $\alpha$ A1 5'gATgTCTTTCCACAACCCTTgggC, located at + 166; FibBßA1 5'CCCgATAgCCACCTCCACTgATG, located at +257;

Fib $\gamma$ A1 5'CCTggACTTCAAAgTAgCAgCgTC, located at +376.

Southern analysis was performed on $10 \mu \mathrm{g}$ of tail biopsy DNA digested with endonuclease Pst I (Stratagene) according to the supplier, separated on a $0.8 \%$ agarose gel, and then transferred to a Magna Charge nylon membrane (Micron Separations Inc.) by vacuum transfer using the model 785 vacuum blotter (BioRad, Hercules, CA). The membrane was then crosslinked by UV radiation using a UV crosslinker model FB-UVXL-1000 (Fisher Scientific, Pittsburgh, PA). Probes were constructed from a Pst I/ Kpn I promoter fragment and radiolabelled by $\left[\alpha-{ }^{32} \mathrm{P}\right]-$ dATP using a random primer kit (Promega, Madison, WI). Prehybridization and hybridization of each probe was carried out at $68^{\circ} \mathrm{C}$ for $2 \mathrm{~h}$ using QuikHyb (Stratagene). The membrane was washed twice with $2 \mathrm{X} \mathrm{SSC}+0.1 \% \mathrm{SDS}(\mathrm{w} / \mathrm{v})$ for $15 \mathrm{~min}$, and once in $0.1 \mathrm{X} \mathrm{SSC}+0.1 \% \mathrm{SDS}$ at $60^{\circ} \mathrm{C}$ for $30 \mathrm{~min}$, before autoradiography at $-80^{\circ} \mathrm{C}$. Digestion of trigenic mouse DNA with endonuclease Pst I, which cuts each construct at the same site in the promoter region but varies the 3' cut, produced fragment sizes of $4.3 \mathrm{kbp}$ for WAP6FibB $\beta 1,3.0 \mathrm{kbp}$ for WAP6Fib $\gamma 1$ and 2.2 for WAP6FibA $\alpha 1$ (Figure 4). The WAP probe hybridizes with each fragment identically and will also hybridize with a fragment produced by the endogenous WAP gene. Relative copy numbers for each construct within a given line were determined by comparing each lane's internal WAP control (2 copies) to the signal intensity produced for each construct. Signal intensity (by volume determination) from autoradiographic film was performed using a densitometer and the corresponding Image Quant software (Molecular Dynamics, Sunnyvale, CA)

Isolation and measurement of $m R N A$ 
Murine mammary glands (right posterior) from D 5,10 and 15 of lactation were removed, washed in DEPC water, portioned $(100 \mathrm{mg}$ ) into $2.0 \mathrm{ml}$ RNase free microcentrifuge tubes and stored at $90^{\circ} \mathrm{C}$ until processing. Half a $\mathrm{ml}$ of Tri-reagent (Molecular Research Center Inc., Cincinnati, $\mathrm{OH})$ was added to each sample and mechanically homogenized using a Kinematica polytron homogenizer (Brinkman Instruments, Westbury, NY). After homogenization $0.5 \mathrm{ml}$ of Trireagent was added and manufacturer's protocol was then followed.

Assessment of mRNA size by was performed Northern analysis on total isolated RNA similar to procedures of Paleyanda et al. (1994). Briefly, $10 \mu \mathrm{g}$ of total RNA was loaded onto $2.5 \%$ formaldehyde, $1.2 \%$ agarose gels, electrophoresed for $3 \mathrm{~h}$ at $100 \mathrm{v}$, blotted and probed identically as Southern blots. Probes consisted of the full length cDNAs of hfibB $\beta$ and hfib $\gamma$, and the 1.0 kbp Kpn I fragment of the hfibA $\alpha$ cDNA. Total human liver RNA (Clonetech, Palo Alto, CA) was used as a positive control.

Quantitative measurement of total mammary RNA was performed by slot blot analysis. Samples were blotted onto a Magna Charge nylon membrane using a Bio-Dot SF microfiltration apparatus (BioRad). Before blotting, samples were added to $25 \mu \mathrm{l}$ of denaturation solution [64\% formamide, $8.5 \%$ formaldehyde , and 0.66X MOPS running buffer (5X MOPS buffer, $0.1 \mathrm{M}$ MOPS pH 7.0, $40 \mathrm{mM} \mathrm{Na}$ acetate, $5 \mathrm{mM}$ EDTA)] and subjected to $50^{\circ} \mathrm{C}$ for $15 \mathrm{~min}$. Two hundred $\mu$ l of $2.5 \%$ formaldehyde was added to the solution and samples were applied to the apparatus. After blotting, sample wells were washed with $200 \mu 1$ of $2.5 \%$ formaldehyde and the membrane processed and probed identical to Northern analysis. Signal quantification (by volume determination) from autoradiographic film was performed using a densitometer and the corresponding Image Quant software (Molecular Dynamics). A standard curve was produced for each film using the curve fitting option in Slide Write software (Advanced Graphics Software, Carlsbad, CA) with the sample signal intensities correlated to ng of total human RNA.

\section{Collection and processing of mouse milk}

Milk from transgenic and control mice was directly collected into $1.7 \mathrm{ml}$ centrifuge tubes by vacuum aspiration, with $200 \mu \mathrm{l}$ of milk removed, added to $200 \mu \mathrm{l}$ of milk buffer $(50 \mathrm{mM}$ Tris and $200 \mathrm{mM}$ EDTA $\mathrm{pH} 8.5$ ) and frozen at $-90^{\circ} \mathrm{C}$. Milk samples were defatted by centrifugation at $15,000 \mathrm{x} \mathrm{g}$ in a bench top centrifuge for $20 \mathrm{~min}$ at $4^{\circ} \mathrm{C}$. After skimming, the resulting clarified milk (prepared whey) was stored at $-90^{\circ} \mathrm{C}$ until analysis.

\section{Western analysis}

Gel electrophoresis was carried out on polyacrylamide gradient gels from Novex (San Diego, CA), 8 to $16 \%$ for reducing conditions and 4 to $12 \%$ for nonreducing conditions using TrisGlycine buffer (25 mM Tris, $0.1 \%$ SDS and $200 \mathrm{mM}$ glycine). Unless otherwised noted, $1 \mu 1$ of clarified milk was loaded per sample and electrophoresed until the 7.0 KDa marker reached the end of the gel or ran off. Gels were transferred to PVDF membranes (BioRad) in Towbin buffer 
(10\% Methanol, $200 \mathrm{mM}$ glycine, $25 \mathrm{mM}$ Tris, $0.1 \%$ SDS) at $4^{\circ} \mathrm{C}$, at $200 \mathrm{~mA}$ overnight using a BioRad Trans-blot cell. Membranes were blocked using TBSTC ( $20 \mathrm{mM}$ Tris, $50 \mathrm{mM} \mathrm{NaCl}$, $0.05 \%$ Tween $20,0.5 \%$ bovine casein, $\mathrm{pH}$ 7.2) with gentle agitation. Blots were probed with a primary antibody for $1 \mathrm{~h}$ at $37^{\circ} \mathrm{C}$ with gentle agitation. Primary antibodies and the concentrations used were: ADI (1:1000), rabbit polyclonal for all three fib chains (American Diagnostica Inc.); Y18 mAb (1:1000), mouse monoclonal for $A \alpha$-chain; Shainoff $m A b$ (1:300), mouse monoclonal for B $\beta$-chain; NS15 pAb (1:150), rabbit polyclonal for $\gamma$-chain. The Y18 mAb, Shainoff mAb and NS15 pAb were kindly provided by Susan Lord (University of North Carolina; Chapel Hill, NC). After incubation, the blots were rinsed in 1X TBST (20 mM Tris, $50 \mathrm{mM} \mathrm{NaCl}, 0.05 \%$ Tween 20, pH 7.2) for 5 min. Secondary antibodies were then added and incubated for $1 \mathrm{~h}$ at $37^{\circ} \mathrm{C}$. Secondary used antibody for ADI and Y18 pAb was A8275 (1:1000 dilution) anti-rabbit IgG (Sigma Chemical Co., St Louis, Mo.). Secondary antibody for Y18 mAb and Shainoff mAb was A4416 (1:1000 dilution) anti-mouse IgG (Sigma Chemical Co.). After incubation the blots were rinsed three times in deionized water and developed according to manufacturer's instructions for 1 to 10 min using metal enhanced DAB (Pierce, Rockford, IL). Deglycosylation experiments were performed using Endoglycosidase-H or PNGase (New England Biolabs, Beverly, MA) with 150 units per mg of protein, per manufacturer's instructions. Duplicate gels were loaded with $440 \mathrm{ng}$ of treated hfib, $170 \mathrm{ng}$ of treated rhfib and $110 \mathrm{ng}$ untreated hfib control. Samples were electrophoresed and blotted as above and probed with either dimB pAb or dimG pAb (1:5000), rabbit polyclonal (Chemicon Intl. Inc., Temecula, CA). Human fibrinogen standard was provided by the American Red Cross.

\section{Detection of rhfib by ELISA}

The level of rhfib in the whey samples was determined by polyclonal ELISA. Plasma derived hfib was used as a reference standard. Immulon II microtiter plates were coated with $5 \mathrm{mg} / \mathrm{ml}$ of rabbit anti-hfib diluted in $0.1 \mathrm{M} \mathrm{NaHCO}_{3}$, pH 9.6. Wells were washed with TBST and $100 \mathrm{ng}$ of hfib reference, transgenic whey or nontransgenic whey dilutions were added to the plate and incubated for $30 \mathrm{~min}$ at $37^{\circ} \mathrm{C}$. Wells were washed with TBS/Tween and 1:10,000 diluted HRPconjugated rabbit anti-human fibrinogen (Dako, Carpinteria, CA) was added to all wells and incubated for $30 \mathrm{~min}$ at $37^{\circ} \mathrm{C}$. Upon completion of incubation the wells were washed and 100 $\mathrm{ml}$ of OPD (O-phenylenediamine, Abbott Labs, Abbott Park, IL) solution was added to each well. The reaction was stopped after 3 to 4 min by the addition of $100 \mu l$ of $3 \mathrm{~N} \mathrm{H}_{2} \mathrm{SO}_{4}$ and the absorbance was measured at $490 \mathrm{~nm}$.

\section{Generation of transgenic animals}

\section{Results}

A summary of zygote manipulations for the production of transgenic animals used in this study is provided in Table 1. Pronuclear microinjection with an equal molar ratio of the three constructs at a total DNA concentration of $15 \mu \mathrm{g} / \mathrm{ml}$ into zygotes resulted in poor survivability $(38.8 \%)$ and 
a low pregnancy rate $(7.1 \%)$. Therefore, the DNA concentration was lowered to $5 \mu \mathrm{g} / \mathrm{ml}$ to increase the chances of producing transgenic animals. At the lower DNA concentration both an increase in survivability of zygotes $(63.6 \%)$ and pregnancy rate $(70.5 \%)$ were observed with the injection of all three constructs. When the constructs were injected singly at the same concentration similar results were obtained. Overall, nine triple transgenic (WAP6FibT.C.), 11 WAP6FibA $\alpha 1$, nine WAP6FibB $\beta 1$ and eight WAP6Fib $\gamma 1$ founder animals were identified by PCR screening of tail tissue, resulting in integration efficiencies that ranged from 23 to $47 \%$ of pups born. Due to the potential mosaic nature of founder animals, each founder was mated to produce at least 30 offspring to determine germline transmissibility of the transgenes. The number of founder animals transmitting the transgene to their offspring to produce study lines was: $\mathrm{n}=6$ for WAP6FibT.C., $\mathrm{n}=6$ WAP6FibA $\alpha 1, \mathrm{n}=6$ WAP6FibB $\beta 1$ and $\mathrm{n}=2$ WAP6Fib $\gamma 1$, with a frequency of transgene transmission to offspring ranging from 13 to $69 \%$, (see appendix, Table 6). Southern analysis of each established line was performed to verify PCR results and to quantify the number of transgenes within the integration site. The four bands produced by Southern analysis of trigenic mouse DNA are illustrated in Figure 5. The fragment produced by the endogenous WAP genes $(\sim 5.2 \mathrm{kbp})$ acts as an internal control for variations in the actual amount of DNA loaded during gel electrophoresis, due to the presence of endogenous WAP at two copies per diploid genome. By comparing the signal intensities for a given lane, the relative copy numbers of each transgene within the integration site were determined and are presented in Table 2. The composition of some integration sites carried a relatively equal number of each construct (lines 18 and 30) which is to be expected from equal molar injection. However, other lines (2, lanes 1 to $3 ; 10$, lanes 4 and 5; 21, lanes 9 to 11 and 37, lanes 15 to 17) had imbalanced ratios of the genes present.

\section{Expression of fibrinogen $m R N A s$}

To determine if the mRNA for each chain is expressed and the correct size, Northern analysis was performed on mammary tissue. A total of $10 \mu \mathrm{g}$ of isolated mammary RNA was loaded and run concurrently with varying amounts of total human liver RNA (1, 5 and $10 \mu \mathrm{g})$ and probed. Northern analysis using the $\mathrm{A} \alpha, \mathrm{B} \beta$, and $\gamma$ chain probes are shown in Figure 6 . The expected mRNA sizes for each construct without addition of a poly-adenylation tail but including 34 bases of 5' UTR and 95 bases 3' UTR derived from the WAP gene elements are: WAP6FibA $\alpha 1,1935$ bases; WAP6FibB $\beta 1,1512$ bases; and WAP6Fib $\gamma 1,1357$ bases.

Slot blot analysis was performed to estimate the amount of each fibrinogen chain mRNA being produced in mammary tissue as compared to the amount of each fibrinogen chain mRNA present in human liver. The signal intensity produced by total mammary RNA (10 $\mu \mathrm{g})$ was compared to the signal standard curve produced by step dilutions of total human liver RNA. Therefore, the signals produced from mammary samples were converted to relative amounts of total human liver RNA on a per weight bases. Results from selected mice are presented in Table 3 as ng of 
human liver total message per $10 \mu \mathrm{g}$ of total mammary RNA. For example, $100 \mathrm{ng} / 10 \mu \mathrm{g}$ of total mammary RNA would indicate a mRNA level of $1 / 100^{\text {th }}$ of that in $10 \mu \mathrm{g}$ of total human liver RNA. The trigenic lines 2, 18 and 30 did not have any detectable mRNA or fib subunits being secreted into their milk.

Identification of assembled fibrinogen and fib chain complexes in milk

To determine if the mRNAs for each chain are translated properly, milk samples from mRNA expressing lines were subjected to Western blotting. Figure 7 shows $1 \mu \mathrm{l}$ of defatted milk from select animals separated by SDS-PAGE under reducing conditions and probed with the polyclonal antibody ADI which recognizes all three fib chains. The migration of the mouse milk rhfib $\mathrm{A} \alpha$ and $\mathrm{B} \beta$ chains is identical to human standard, lane 1, but the gamma chain has a slightly faster mobility. The amount of each chain present differs among different mouse lines and mice within a given line. For example, The $\mathrm{B} \beta$ chain is present in varying amounts in mice from line 37 (lanes 3 to 5) with the strongest signal being produced by milk from line 10 mouse 10.28 (lane 8). In contrast, milk samples from mouse 37.21 and 21.14 have no detectable B $\beta$ chain. Also present are several higher molecular weight species which most likely represent incomplete reduction and separation of fibrinogen and/or fibrinogen chain complexes. In order to identify the degree of secreted subunit assembly, identical samples were run under nonreducing conditions and probed with the same ADI antibody, (Figure 8). The antibody recognizes only a single band in the human standard, lane 1; but also binds to mouse fibrinogen with a low affinity in lane 2. Trigenic milk samples have several bands present, indicating secretion of individual chains or chain complexes. There are two prominent bands (A and AG) with apparent sizes of 66 and 135-150 KDa, respectively, which correspond to A $\alpha$ chain monomers and an $A \alpha \gamma_{2}$ chain complex. The monomer form is found secreted in all lines studied (lanes 3 to 8). The A $\alpha$ monomer signal produced by milk from mouse 10.28 (lane 8 ) is more intense than that produced by milk from mice of line 21 or 37 (lanes 3 to 7 ), but in contrast band AG is very weak in 10.28 and very strong in the other two lines. These observations along with the absences of bands below $206 \mathrm{KDa}$ in the control milk sample (lane 2) indicate individual chains and partial chain complexes can be secreted by the mammary gland. The other minor bands present in the transgenic milk samples maybe the association of free chains or chain complexes with the alpha caseins, which are known to interact among themselves via cystine bridging. In order to identify whether the $A$ band is free $A \alpha$-chain and the AG band contains the $A \alpha$ subunit, a nonreduced blot was probed with an $A \alpha$-chain specific monoclonal antibody (Figure 9). Lanes 1 and 2 are hfib $200 \mathrm{ng}$ and control mouse milk, respectively. Lanes 3 to 5 are milk samples from mouse 10.28 during her second lactation (days 6, 10, 15); lanes 6 and 7 are from line 21 high and nonexpressing mice, respectively; and lanes 8 and 9 are from two mice from the 37 line. There are four major bands identified: A at $\sim 66 \mathrm{KDa}, \mathrm{AG}$ at $\sim 130-150 \mathrm{KDa}$, mIg at $\sim 180 \mathrm{KDa}$ and fib 
Table 1. Summary of murine zygote manipulations.

\begin{tabular}{|c|c|c|c|c|c|c|}
\hline & $\begin{array}{l}\text { WAP6Fib-T.C. } \\
\qquad 15 \mu \mathrm{g} / \mathrm{ml}^{\mathrm{a}}\end{array}$ & $\begin{array}{l}\text { WAP6Fib-T.C. } \\
5 \mu \mathrm{g} / \mathrm{ml}\end{array}$ & $\begin{array}{c}\text { WAP6Fib-A } \alpha 1 \\
5 \mu \mathrm{g} / \mathrm{ml}\end{array}$ & $\begin{array}{c}\text { WAP6Fib-B } \beta 1 \\
5 \mu \mathrm{g} / \mathrm{ml}\end{array}$ & $\begin{array}{l}\text { WAP6Fib- } \gamma 1 \\
5 \mu \mathrm{g} / \mathrm{ml}\end{array}$ & TOTAL \\
\hline Number Injected & 1275 & 1605 & 1118 & 2266 & 570 & 6834 \\
\hline Number Transferred & 495 & 1022 & 667 & 1291 & 316 & 3791 \\
\hline Percent Survived & $(38.8)$ & (63.6) & $(64.5)$ & $(58.7)$ & (63.3) & $(57.3)$ \\
\hline Number Recipients & 14 & 17 & 13 & 21 & 5 & 70 \\
\hline Zygotes/Recipient & 35.3 & 60.1 & 51.3 & 61.4 & 63.2 & 54.1 \\
\hline Pregnancies & 1 & 12 & 7 & 10 & 4 & 34 \\
\hline Pregnancy Rate & $(7.1)$ & $(70.5)$ & $(58.8)$ & $(47.6)$ & $(66.6)$ & $(48.5)$ \\
\hline Pups Born & 1 & 39 & 37 & 31 & 17 & 125 \\
\hline Pups/Litter & 1 & 3.2 & 5.3 & 3.1 & 4.2 & 3.6 \\
\hline Number Transgenic & 1 & 9 & 11 & 9 & 8 & 38 \\
\hline $\begin{array}{c}\text { Integration } \\
\text { efficiency (\%) }\end{array}$ & $(100)$ & $(23.0)$ & $(29.7)$ & $(29.0)$ & $(47.0)$ & $(30.4)$ \\
\hline
\end{tabular}

Zygotes at the pronuclear stage of development were collected and microinjected as described in materials and methods. The three constructs WAP6FibA $\alpha 1$, WAP6FibB $\beta 1$ and WAP6Fib $\gamma 1$ were injected equal molar to produce WAP6FibT.C. (T.C. = triple construct) transgene mice or singly to produce monogenic lines. ${ }^{a}$ Concentration of DNA construct microinjected into zygotes. 


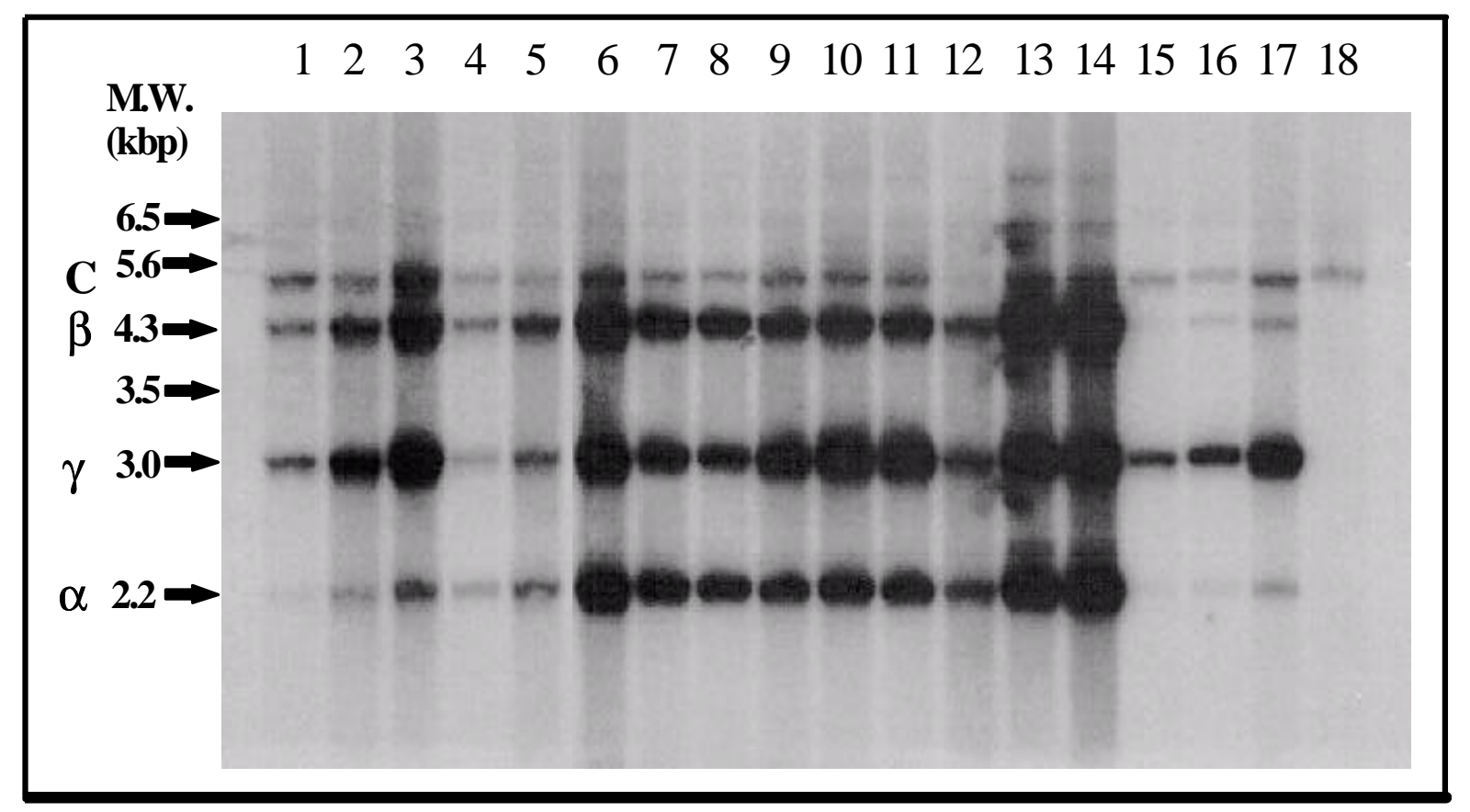

Figure 5. Southern analysis of transgenic mice containing the three constructs WAP6FibA $\alpha 1$, WAP6FibB $\beta 1$ and WAP6Fib $\gamma 1$.

DNA samples from mice of each established trigenic line were subjected to Southern analysis. The four bands detected are: $\alpha$, the $2.2 \mathrm{kbp}$ fragment generated by WAP6FibAa1; $\gamma, 3.0 \mathrm{kbp}$ fragment from WAP6Fiby1; $\beta, 4.3 \mathrm{kbp}$ fragment from WAP6FibB $\beta 1$; and $\mathbf{C}, \sim 5.2 \mathrm{kbp}$ fragment generated by the endogenous WAP gene. Lanes are: 1 , founder \#2; $2+3$, offspring 2.5 and $2.18 ; 4$, founder \#10; 5 , offspring $10.13 ; 6$, founder \#18; 7+8, offspring 18.10 and 18.19; 9, founder \#21; 10+11, offspring 21.14 and 21.18; 12, founder \#30; lanes 13+14, offspring 30.4 and 30.10; 15, founder \#37; 16+17, offspring 37.4 and $37.7 ; 18$, control mouse. 
Table 2. Transgene copy number summary for trigenic lines.

\begin{tabular}{||c|c|c|c||}
\hline Mouse line & WAP6FibA $\alpha 1$ & WAP6FibB $\beta 1$ & WAP6Fib $\gamma 1$ \\
\hline$\# 2$ & 1 & 4 & $6-8$ \\
\hline$\# 10$ & $4-6$ & 2 & 4 \\
\hline$\# 18$ & 8 & $8-10$ & $8-10$ \\
\hline$\# 21$ & 8 & 6 & $12-16$ \\
\hline$\# 30$ & 8 & 10 & 8 \\
\hline$\# 37$ & 1 & 1 & $8-10$ \\
\hline
\end{tabular}

The copy number for each construct within a given mouse line was determined by comparing the band signal intensity produced by Southern analysis of the endogenous gene to the construct genes. 


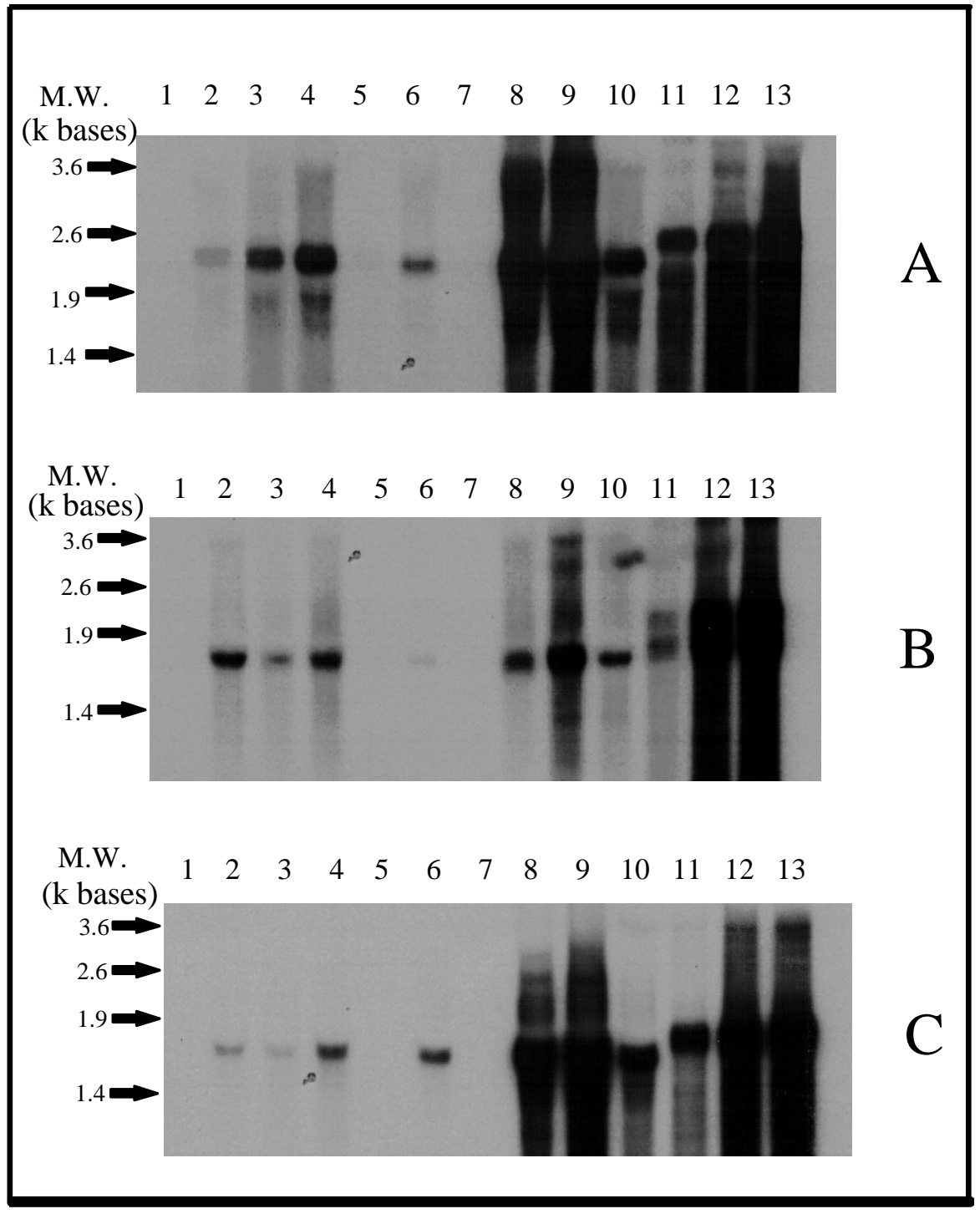

Figure 6. Northern analysis of total murine mammary RNA.

$10 \mu \mathrm{g}$ of total mammary RNA was loaded in each lane and run concurrently with total human liver RNA, blotted and probed with: A, $1.0 \mathrm{kbp}$ alpha chain cDNA fragment; B, $1.4 \mathrm{kbp}$ beta chain cDNA fragment and C, $1.2 \mathrm{kbp}$ gamma chain cDNA fragment. day of lactation $=\mathrm{D}$. Lane samples are as follows: 1, control mouse D10; 2, mouse 10.27.5.5 D5; 3, 10.27.5.1 D10; 4, 10.27.1 D15; D 5, 21.2.2 D 5; 6, 21.3.4 D10; 7, 21.2 D16; 8, 37.21 D 5; 9, 37.7 D10; 10, 37.12 D15; 11, $1 \mu \mathrm{g}$ of total human liver RNA; 12, $5 \mu \mathrm{g}$ of total human liver RNA; $13,10 \mu \mathrm{g}$ of total human liver RNA. The expected mRNA sizes for each transgene without their poly-A tail are: alpha, 1935 bases; beta, 1512 bases; and gamma , 1357 bases. 
Table 3. Expression of mRNA and subunit concentration of select mice.

\begin{tabular}{|c|c|c|c|c|}
\hline \multirow[t]{2}{*}{ Mouse I.D. } & \multicolumn{3}{|c|}{$\begin{array}{c}\text { Fibrinogen mRNA Expression } \\
\text { (ng of human liver signal / } 10 \mu \mathrm{g} \text { total mammary RNA) }\end{array}$} & \multirow{2}{*}{$\begin{array}{l}\text { Concentration of } \\
\text { fibrinogen subunits } \\
\text { in milk }(\mu \mathrm{g} / \mathrm{ml})\end{array}$} \\
\hline & $\mathrm{A} \alpha$-chain mRNA & $\mathrm{B} \beta$-chain mRNA & $\gamma$-chain mRNA & \\
\hline 10.28 & 2242 & 1844 & 1514 & 450 \\
\hline 21.3 .4 & 143.9 & 69 & 486 & 20 \\
\hline 37.7 & 11326 & 7020 & 23262 & 590 \\
\hline
\end{tabular}

The detection of mRNA was by slot blot analysis and the concentration of subunits was determined by polyclonal ELISA . 
$\sim 340 \mathrm{KDa}$. The concentration of the A band is found most abundantly in samples from mouse 10.28 (lanes 3 to 5) with lower levels found in samples from line 37 mice (lanes 8 and 9) and the line 21 high expresser (21.3) mouse (lane 6). In contrast, the AG band was found most intense in milk samples from line 37 mice and 21.3 (lanes 6, 8 and 9) with low concentrations in 10.28 samples (lanes 3 to 5). These observations indicate that free $\mathrm{A} \alpha$-chain is secreted by the mammary gland. Also it has a higher molecular weight complex containing at least the A $\alpha$ subunit. The antibody also identified assembled hfib in whey from expressing mice with some crossreactivity to mouse fib that migrates slightly faster than hfib (top band in lane 2 and 7). The $\mathrm{mIg}$ band produced in all mouse samples was due to recognition of secreted $\operatorname{IgG}$ by the secondary conjugated antibody (A4416, anti-mouse) used.

To evaluate whether $\mathrm{B} \beta$-chain was being secreted by these mice as free chain or as a complex, a blot using a monoclonal $\mathrm{B} \beta$ subunit antibody was performed and is shown in Figure 10. Only two significant bands were identified, the mIg band previous discussed and the fib band found only in mRNA-expressing mice and migrating identically to the human standard. These observations indicate that the beta chain is being produced at a level where it is incorporated into fully assembled fib. Since this antibody does not crossreact with mouse fib, the relative amounts of rhfib secreted among different mice can be observed. To follow the pattern of secretion for the $\gamma$-chain and to rule out the possibility that the AG band in Figure 9 was not an oligomer of $A \alpha$ subunits, a $\gamma$-subunit blot was performed using a gamma chain specific polyclonal antibody, (Figure 11). Four bands are produced: $\mathrm{G}$ at $\sim 46 \mathrm{KDa}, \mathrm{GG}$ at $\sim 90 \mathrm{KDa}, \mathrm{AG}$ at $\sim 130-150 \mathrm{KDa}$ and fib at $\sim 340 \mathrm{KDa}$. The fib band was found in all mRNA expressing mice and in the human standard. The AG band was not detected in milk from mouse 10.28 (lanes 3 to 5) but was present in milk samples from mice of line 37 (lanes 8 and 9) and the line 21 high expresser 21.3 (lane 6). The two other bands $\mathrm{G}$ and $\mathrm{GG}$ were only found in line 37 mice and migrate at the size ranges calculated for the monomeric and dimeric forms of this chain.

\section{Glycosylation pattern of rhfib beta and gamma subunits}

Deglycosylation experiments were conducted to explore the rate limitations of the murine mammary gland in adding complex saccharides to the $B \beta$ and $\gamma$ subunits of rhfib secretion products. Human fib (440 ng) and rhfib from mouse line 37 whey (170 ng) were subjected to digestion with the enzymes Endoglycosidase $\mathrm{H}$ (high mannose, Endo$\mathrm{H}$ ) or Glycopeptidase (high mannose or complex, PNGase) that cleave N-linked saccharides. Figure 12 shows digestion products, separated, blotted and probed by a B $\beta$ chain polyclonal antibody. The higher molecular weight band (marked $A \alpha$ ) appears to be due to crossreaction of the antibody with the alpha chain, as indicated by the size of the 


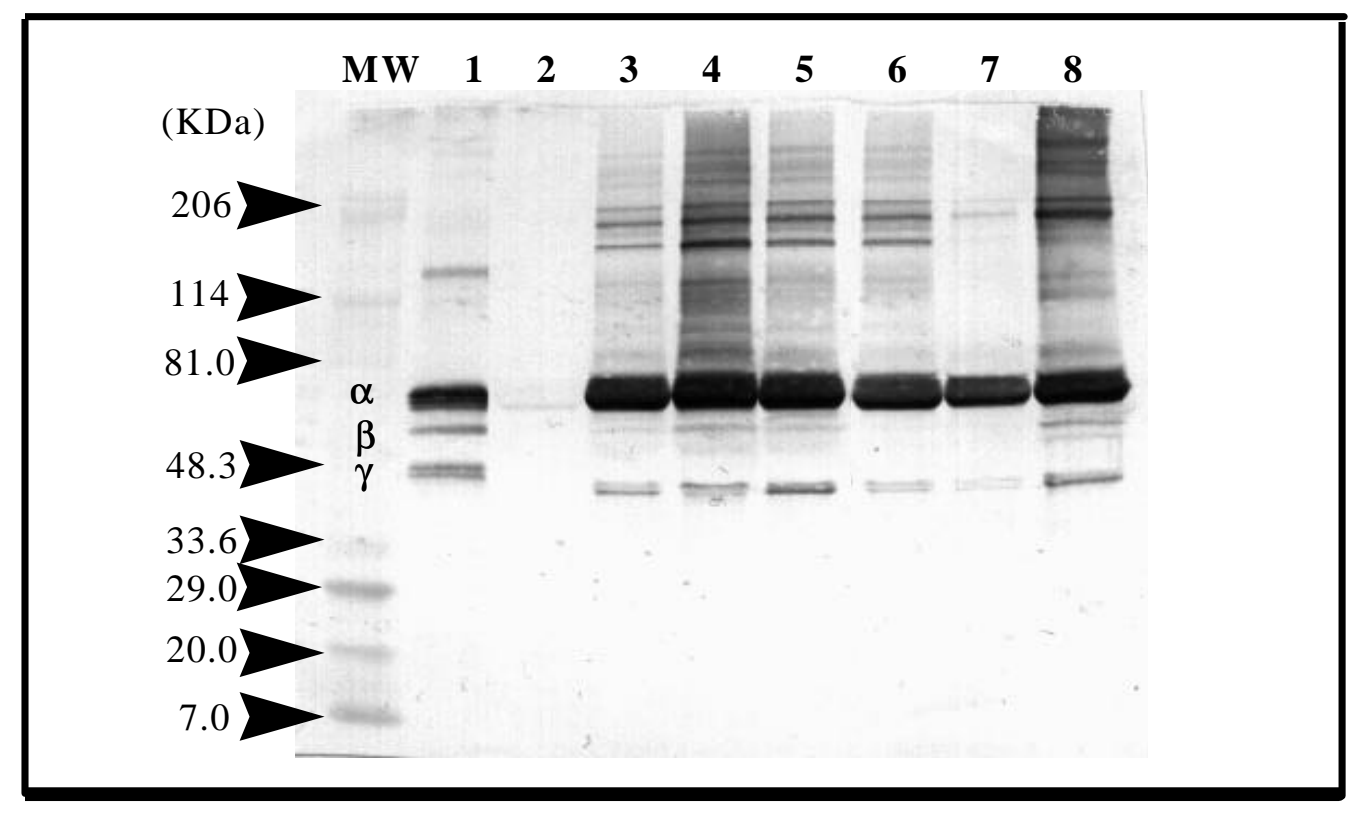

Figure 7. Reduced Western blot of WAP6FibT.C. mouse milk

Purified whey from transgenic animal milk was separated by PAGE under reducing conditions, blotted and probed with polyclonal antibody. day $=\mathrm{D}$, lactation $=\mathrm{L}$. Lane samples are: MW, molecular weight markers; 1 , hfib 160ng; 2, nontransgenic mouse defatted milk; 3, mouse $37.7 \mathrm{D} 5,1^{\text {st }} \mathrm{L} ; 4$, mouse $37.7 \mathrm{D} 10,3^{\text {rd }} \mathrm{L} ; 5$, mouse $37.4 \mathrm{D} 5,1^{\text {st }} \mathrm{L} ; 6$, mouse $37.21 \mathrm{D} 5,1^{\text {st }} \mathrm{L} ; 7$, mouse $21.14 \mathrm{D} 16,1^{\text {st }} \mathrm{L}$; and 8 , mouse $10.28 \mathrm{D} 15,2^{\text {nd }} \mathrm{L} . \alpha=$ human fibrinogen $\mathrm{A} \alpha$-chain, $\beta=$ human fibrinogen $\mathrm{B} \beta$-chain, $\gamma$ - human fibrinogen $\gamma$-chain. 


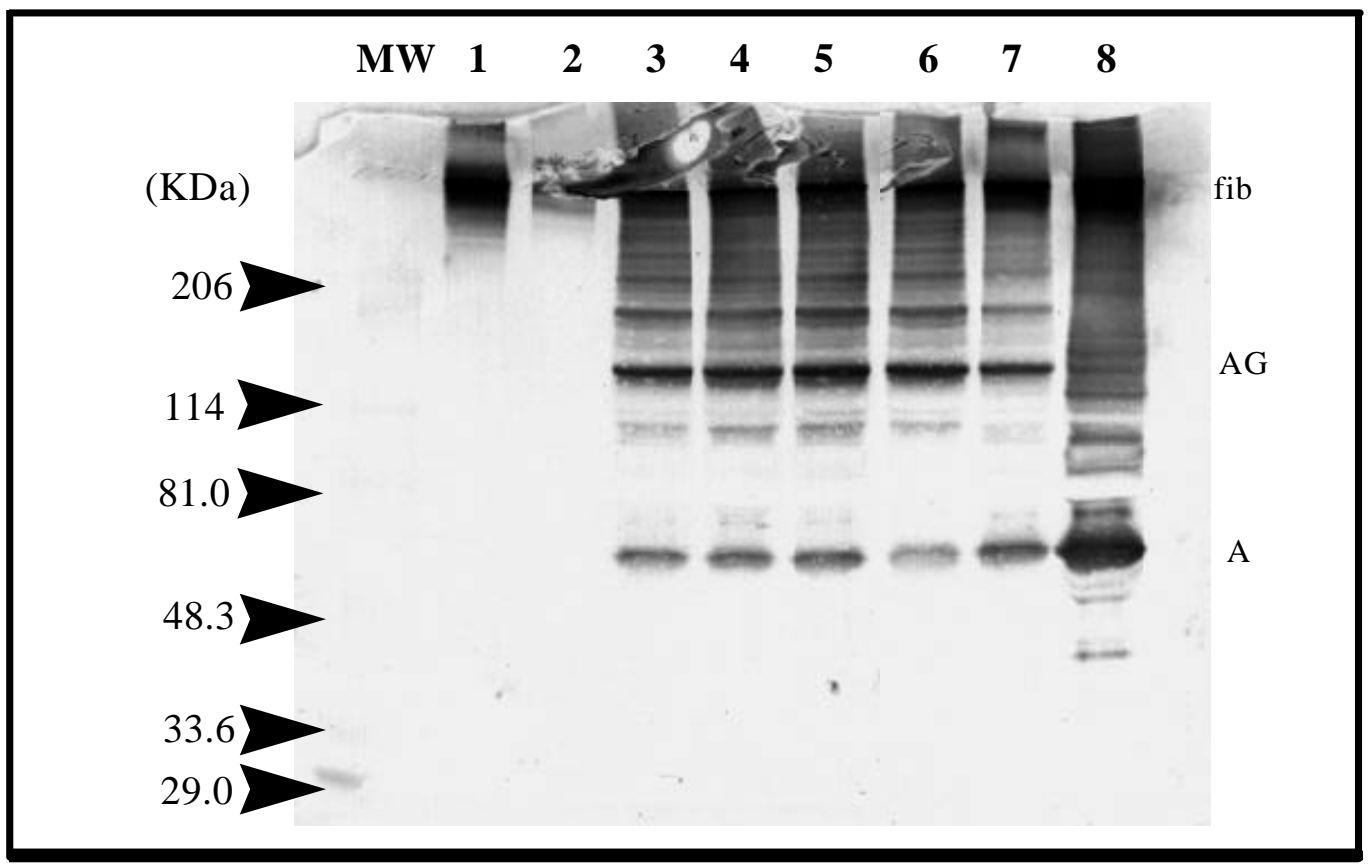

Figure 8. Non reduced Western blot of WAP6FibT.C. mouse milk.

Defatted transgenic animal milk was separated by SDS-PAGE under nonreducing conditions, blotted and probed with a polyclonal antibody which recognizes all three chains. day $=\mathrm{D}$, lactation $=\mathrm{L}$. Lane samples are: $\mathrm{MW}$, molecular weight markers; 1 , hfib $160 \mathrm{ng}$; 2, nontransgenic mouse defatted milk; 3, mouse $37.7 \mathrm{D} 5,1^{\text {st }} \mathrm{L} ; 4$, mouse $37.7 \mathrm{D} 10,3^{\text {rd }} \mathrm{L} ; 5$, mouse $37.4 \mathrm{D} 5,1^{\text {st }}$ $\mathrm{L} ; 6$, mouse $37.21 \mathrm{D} 5,1^{\text {st }} \mathrm{L} ; 7$, mouse $21.14 \mathrm{D} 16,1^{\text {st }} \mathrm{L}$; and 8 , mouse 10.28 $\mathrm{D} 15,2^{\text {nd }} \mathrm{L}$. fib = fibrinogen, $\mathrm{AG}=$ alpha-gamma chain complex, $\mathrm{A}=$ alpha chain monomer. 


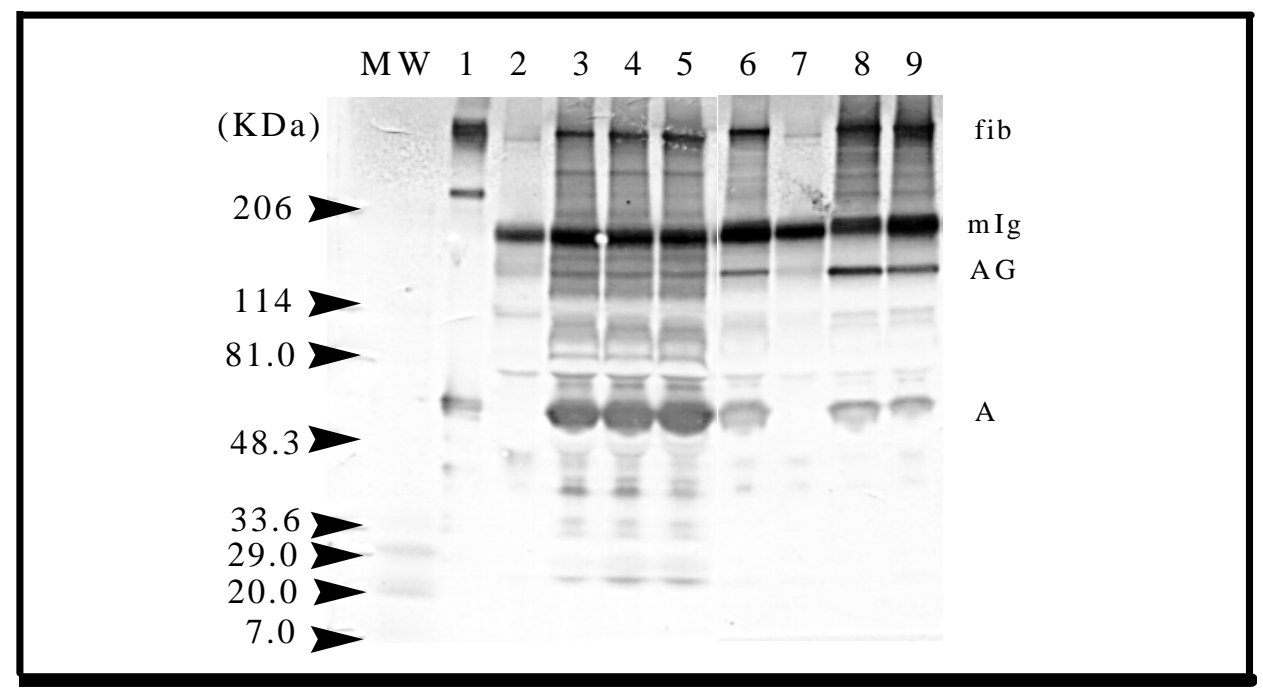

Figure 9. Non-reduced Western analysis for A $\alpha$ - chain of selected WAP6FibT.C. mouse milk.

Defatted trigenic animal milk $(1 \mu 1)$ was separated by SDS-PAGE under non-reducing conditions, blotted and probed with a $A \alpha$-chain specific monoclonal antibody. day $=\mathrm{D}$, lactation $=\mathrm{L}$. Lanes are: $\mathrm{MW}$, molecular weight markers; 1 , hfib 200ng; 2 , control mouse defatted milk; 3-5, mouse 10.28, D6, D10, D15 $2^{\text {nd }} \mathrm{L} ; 6$, mouse 21.3 , D $112^{\text {nd }} \mathrm{L}$; 7, mouse 21.2, D16 $2^{\text {nd }} \mathrm{L} ; 8$, mouse 37.4, D5 1st L; 9, mouse 37.7, D $103^{\text {rd }} \mathrm{L} . A=$ alpha chain monomer, $A G=$ alpha-gamma chain complex, $\mathrm{mIg}=$ mouse $\mathrm{IgG}$, fib = fibrinogen. 
protein. The lack of shifting in comparison with the human standard upon treatment suggest that the $A \alpha$-chain being secreted by mice is not glycosylated. The lower band exhibits band shifting upon hfib treatment with PNGase or rhfib treatment with either Endo-H or PNGase. This indicates that the saccharides of the B $\beta$ chain being secreted by this mouse line are of the high mannose type and not complex. When the same samples are blotted and probed with a $\gamma$-chain specific antibody a different result for the rhfib gamma subunit is observed. Figure 13 illustrates that the saccharide on the $\gamma$-chain is not of the high mannose type but complex in nature as demonstrated by the lack of band shifting upon Endo-H treatment (lane 6). The upper band (marked B $\beta$ ) appears to be crossreaction of the antibody to the $\mathrm{B} \beta$ chain of fibrinogen based on its molecular size and shifting upon PNGase treatment in the human control (lane 4).

\section{Evaluation of monogenic mice}

In order to evaluate the secretion potential of individual chains, monogenic mice were produced that carried only WAP6FibA $\alpha 1$, WAP6FibB $\beta 1$ or WAP6Fib $\gamma 1$. DNA from offspring from established mouse lines was subjected to copy number determination. Table 4 lists relative copy numbers for WAP6FibA $\alpha 1$, WAP6FibB $\beta 1$ and WAP6Fib $\gamma 1$ lines established. After mRNA slot blot analysis of mammary tissue from WAP6FibA $\alpha 1$ mice, only line 43 produced any detectable message. Mouse 43.8 had the highest mRNA expression (168 $\mathrm{ng} / 10 \mu \mathrm{g}$ of mammary tissue from D15) in this line. Defatted milk from mouse 43.8, was subjected to Western analysis using the ADI antibody (Figure 14).

Lanes 3 and 4 show $1 \mu$ l of milk from D 15 and 13 of lactation. The human standard (270 ng) and control whey are in lanes 1 and 2, respectively. The concentration of secreted $A \alpha$-chain was estimated to be $150 \mu \mathrm{g} / \mathrm{ml}$. Secretion of the $\gamma$ chain was not detected in the two established WAP6Fib $\gamma 1$ lines studied, which correlates with the absence of mRNA in the mammary gland of these animals.

In order to determine whether the $\mathrm{B} \beta$-subunit is retained or secreted by mammary epithelia cells, mRNA expressing lines of WAP6FibB $\beta 1$ mice were identified by slot blot analysis. Ranges for mRNA levels observed from the three identified expressing lines are presented in Table 5. As with the WAP6FibT.C. mice, expression varied between lines and among mice within a given line (see appendix tables 11 to 15). Prepared whey from high mRNA expressing mice was subjected to Western analysis under reducing conditions to determine the amount of $\mathrm{B} \beta$-chain secretion. A representative blot from these assays is presented in Figure 15. The $\mathrm{B} \beta$ subunit was secreted into milk of this animal at approximately $100 \mu \mathrm{g} / \mathrm{ml}$. Defatted milk samples from this line were subjected to deglycosylation procedures as performed with the WAP6FibT.C. 37 line, in which band shifting only occurred with PNGase but not with 


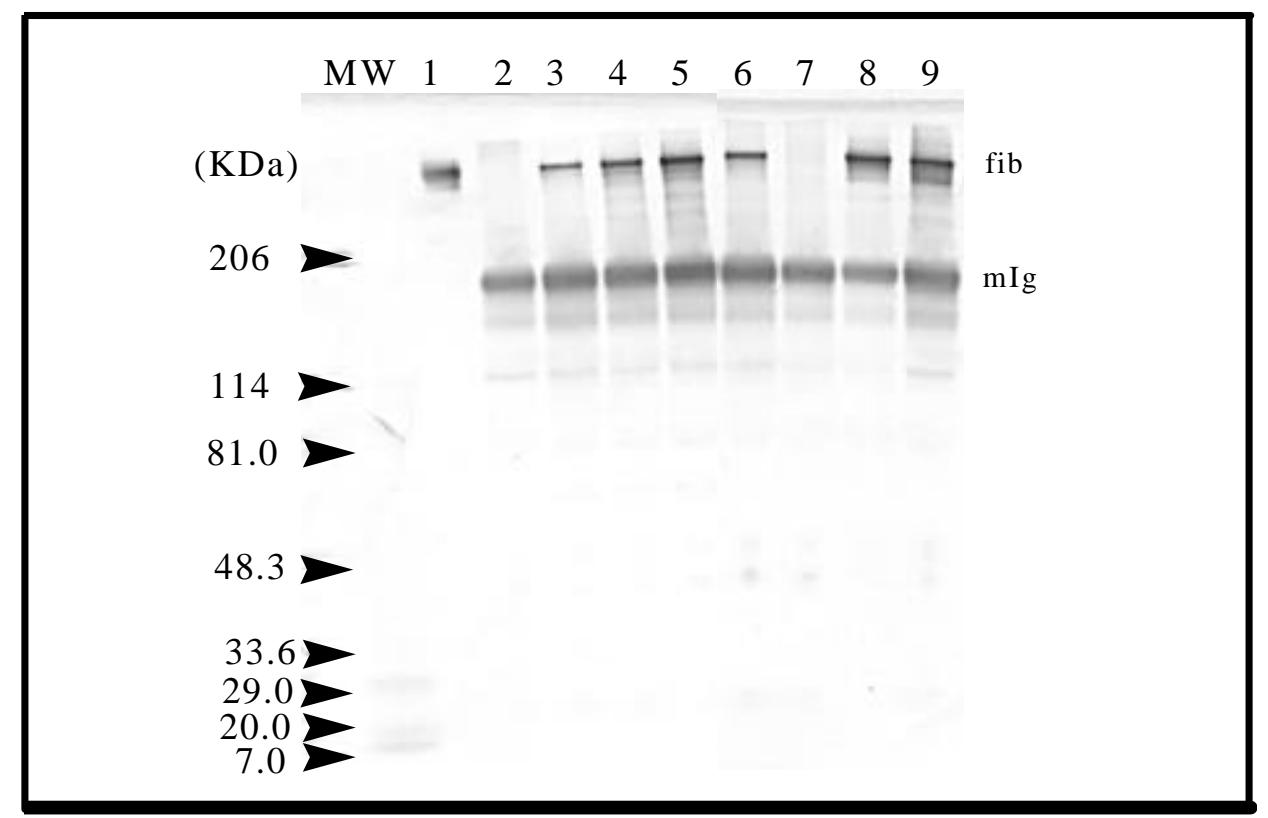

Figure 10. Non-reduced Western analysis for B $\beta$ - chain of selected WAP6FibT.C. mouse milk.

Defatted trigenic mouse milk $(1 \mu 1)$ was separated by SDS-PAGE under non-reducing conditions, blotted and probed with a $B \beta$-chain specific monoclonal antibody. day $=\mathrm{D}$, lactation $=\mathrm{L}$. Lanes are: $\mathrm{MW}$, molecular weight markers; 1 , hfib $200 \mathrm{ng}$; 2, control mouse defatted milk; 3-5, mouse 10.28, D6, 10, $152^{\text {nd }} \mathrm{L} ; 6$, mouse 21.3 , D11 $2^{\text {nd }} \mathrm{L} ; 7$, mouse $21.2, \mathrm{D} 162^{\text {nd }} \mathrm{L} ; 8$, mouse 37.4 , D5 $1^{\text {st }} \mathrm{L} ; 9$, mouse 37.7 , D10 $3^{\text {rd }}$ $\mathrm{L}$. fib $=$ fibrinogen, $\mathrm{mIg}=$ mouse $\mathrm{IgG}$. 


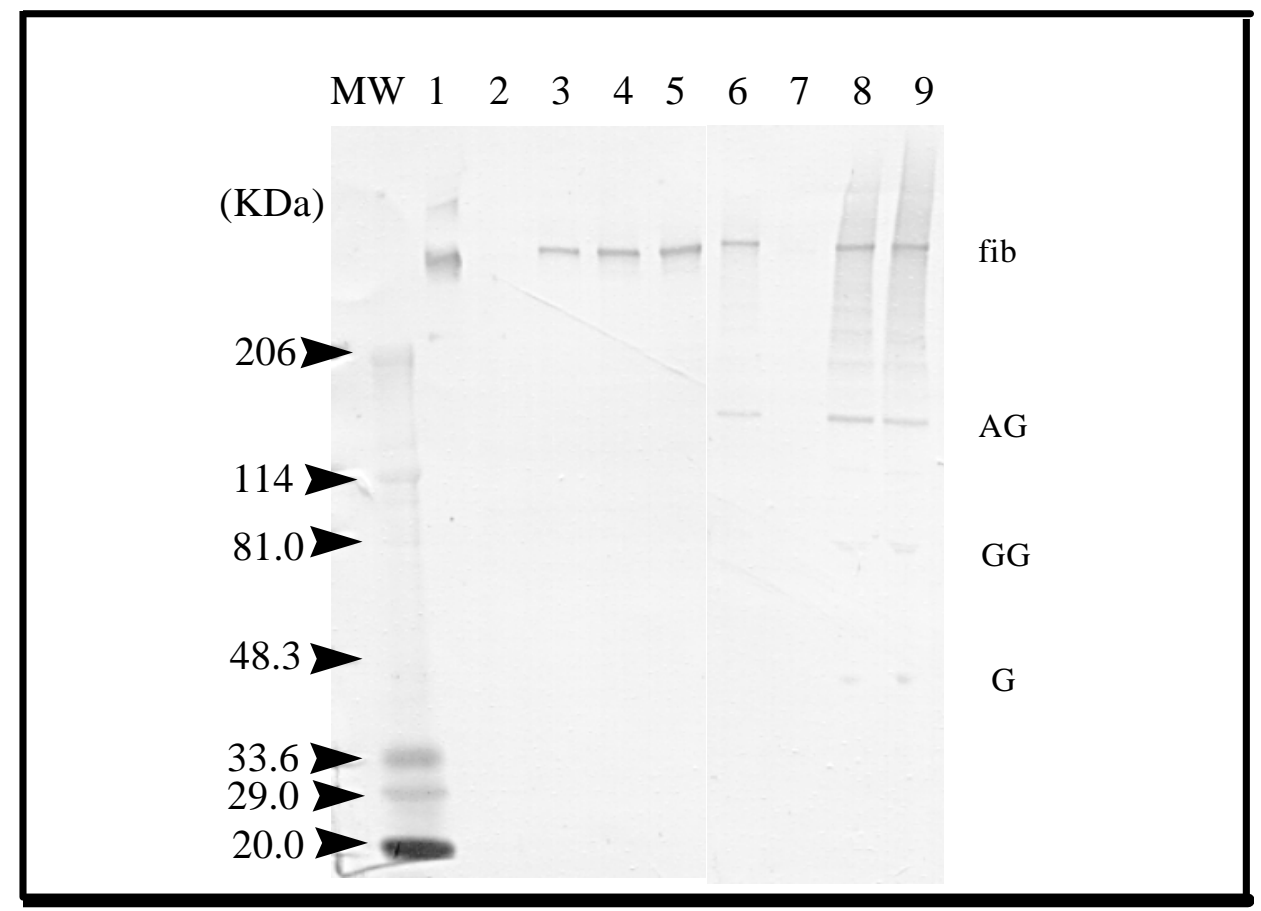

Figure 11. Non-reduced Western analysis for $\gamma$ - chain of selected WAP6FibT.C. mouse milk.

Defatted trigenic mouse milk $(1 \mu \mathrm{l})$ was separated by SDS-PAGE under non-reducing conditions, blotted and probed with a $\gamma$-chain specific polyclonal antibody. day $=\mathrm{D}$, lactation $=\mathrm{L}$. Lanes are: $\mathrm{MW}$, molecular weight markers; 1, hfib $200 \mathrm{ng}$; 2, control mouse defatted milk; 3-5, mouse 10.28 , D6,10,15 $2^{\text {nd }} \mathrm{L} ; 6$, mouse 21.3 , D11 $2^{\text {nd }} \mathrm{L} ; 7$, mouse 21.2 , D16 $2^{\text {nd }} \mathrm{L} ; 8$, mouse 37.4 , D5 $1^{\text {st }} \mathrm{L} ; 9$, mouse 37.7 , D10 $3^{\text {rd }}$ L. fib = fibrinogen, $A G=$ alpha-gamma chain complex, $G G=$ gamma chain dimer, $\mathrm{G}=$ gamma chain monomer. 


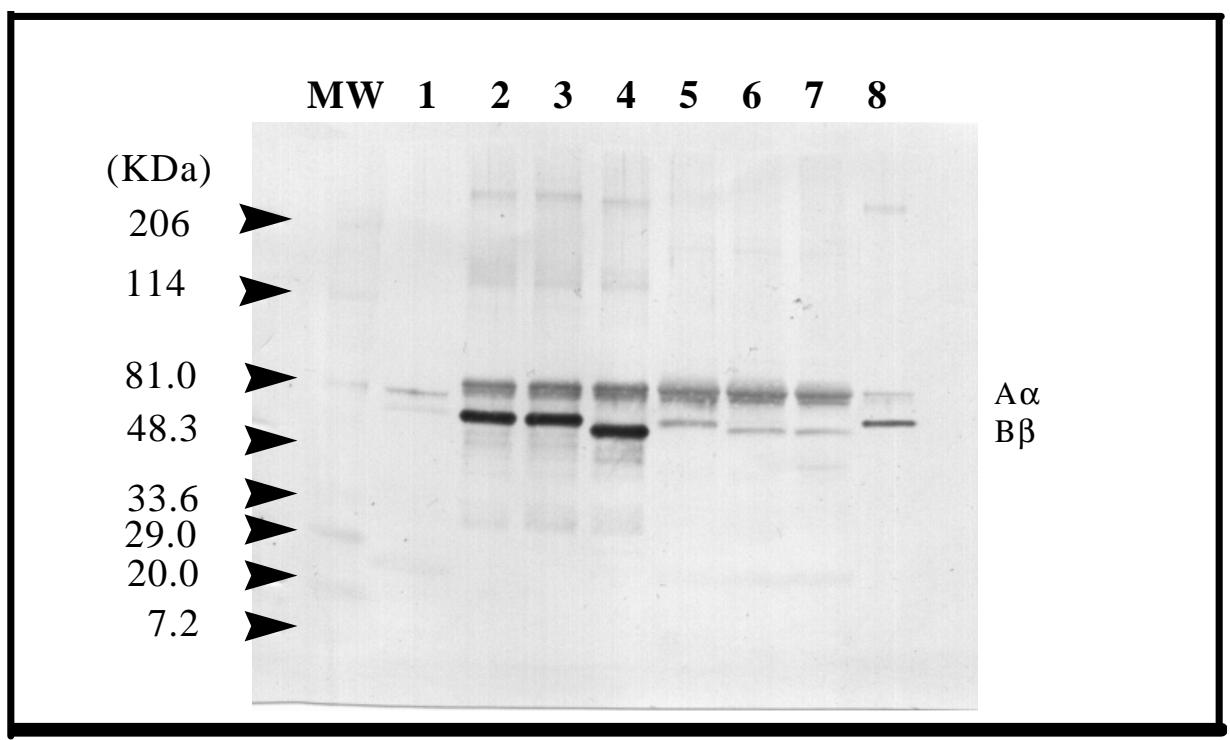

Figure 12. Deglycosylation of human and recombinant fibrinogen $B \beta$-chain.

Human or recombinant fibrinogen was subjected to treatment with endoglycosylsidase $\mathrm{H}$ (Endo $\mathrm{H})$ or PNGase, separated on SDS-PAGE under reducing conditions and probed using a polyclonal B $\beta$-chain specific antibody. Lane samples are: $\mathrm{MW}$, molecular weight markers; 1 , control mouse defatted milk; 2, hfib; 3, hfib + Endo H; 4, hfib +PNGase; 5, defatted trigenic mouse milk pooled from line 37; 6, mouse milk +Endo H; 7, mouse milk+ PNGase; 8 , hfib. A $\alpha$ $=$ alpha chain monomer, $\mathrm{B} \beta=$ beta chain monomer. 


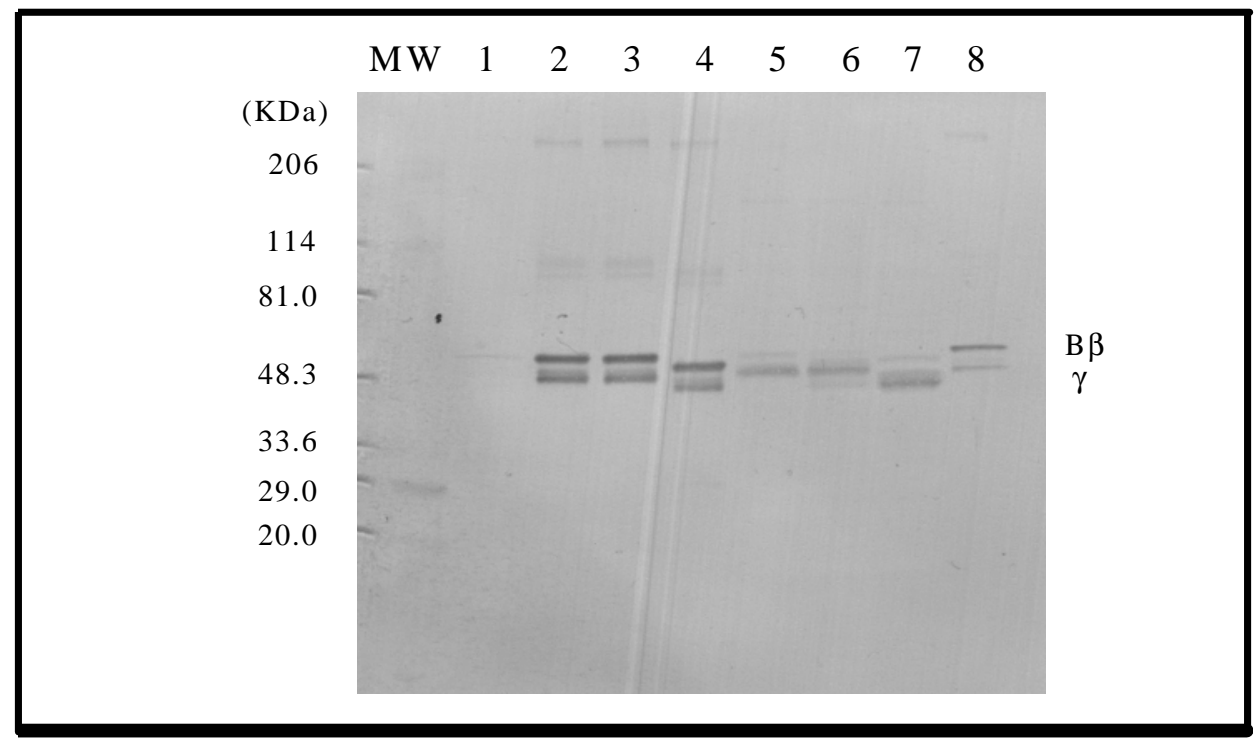

Figure 13. Deglycosylation of human and recombinant fibrinogen $\gamma$-chain.

Human or recombinant fibrinogen was subjected to treatment with endoglycosylsidase H (Endo H) or PNGase, separated on SDS-PAGE under reducing conditions and probed using a polyclonal gamma-chain specific antibody. Lane samples are: MW, molecular weight markers; 1, control mouse defatted milk; 2, hfib; 3, hfib + Endo H; 4, hfib + PNGase; 5, trigenic mouse defatted milk pooled from line 37; 6 , mouse whey + Endo $\mathrm{H} ; 7$, mouse whey + PNGase; 8 , hfib. $\mathrm{B} \beta=$ beta chain, $\gamma=$ gamma chain. 


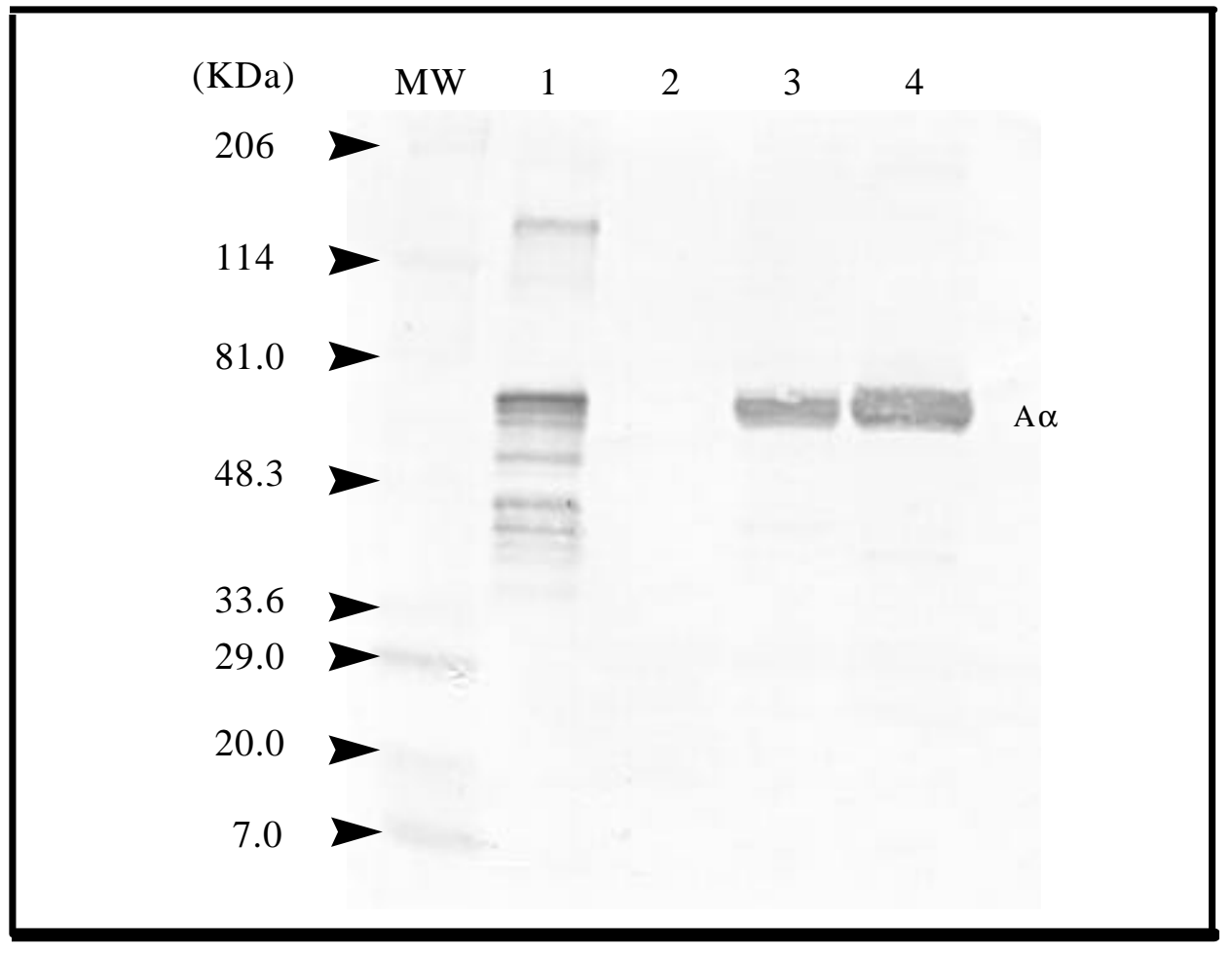

Figure 14. Western blot of WAP6FibA $\alpha 1$ mouse milk.

Defatted milk from a WAP6FibA $\alpha 1$ line 43 mouse was separated by SDS-PAGE and probed with the ADI three chain polyclonal antibody. Lanes are: MW, molecular weight markers; 1, hFib 270 ng; 2, control mouse defatted milk; lane 3 and 4, whey from mouse 43.8 day 15 and 13 of lactation. $\mathrm{A} \alpha=$ alpha chain. 
Table 4. Copy number determination for WAP6FibA $\alpha 1$, WAP6FibB $\beta 1$ and WAP6Fib $\gamma 1$ monogenic mice.

\begin{tabular}{|c|c|c|}
\hline Mouse line & Construct & Copy number \\
\hline 14 & WAP6FibA $\alpha 1$ & $>50$ \\
\hline 26 & & $6-8$ \\
\hline 27 & & 2 \\
\hline 33 & & 2 \\
\hline 43 & & $1-2$ \\
\hline 45 & & 6 \\
\hline 8 & WAP6FibB $\beta 1$ & 7 \\
\hline 14 & & 4 \\
\hline 16 & & 13 \\
\hline 21 & & 14 \\
\hline 25 & & 6 \\
\hline 28 & & 10 \\
\hline 1 & WAP6Fib $\gamma 1$ & $>50$ \\
\hline 6 & & $3-4$ \\
\hline
\end{tabular}

DNA isolated from tail tissue was subjected to Southern analysis and relative copy numbers were determined. 
Table 5. Summary of mRNA expression from expressing WAP6FibB $\beta 1$ lines.

\begin{tabular}{||c|c|c||}
\hline $\begin{array}{c}\text { WAP6FibB } \beta 1 \\
\text { Mouse line }\end{array}$ & $\begin{array}{c}\text { Number of } \\
\text { mice analyzed }\end{array}$ & $\begin{array}{c}\text { Range of B } \beta \text {-chain mRNA expression } \\
\text { (human liver ng total RNA per 10 } \mu \text { g total } \\
\text { mammary RNA) }\end{array}$ \\
\hline 8 & 6 & 0 to 1890 \\
\hline 25 & 3 & 39 to 157 \\
\hline 28 & 3 & 134 to 1835 \\
\hline
\end{tabular}

Mammary samples from WAP6FibB $\beta 1$ lines were subjected to RNA slot blot analysis to determine the relative amount of mRNA present. 


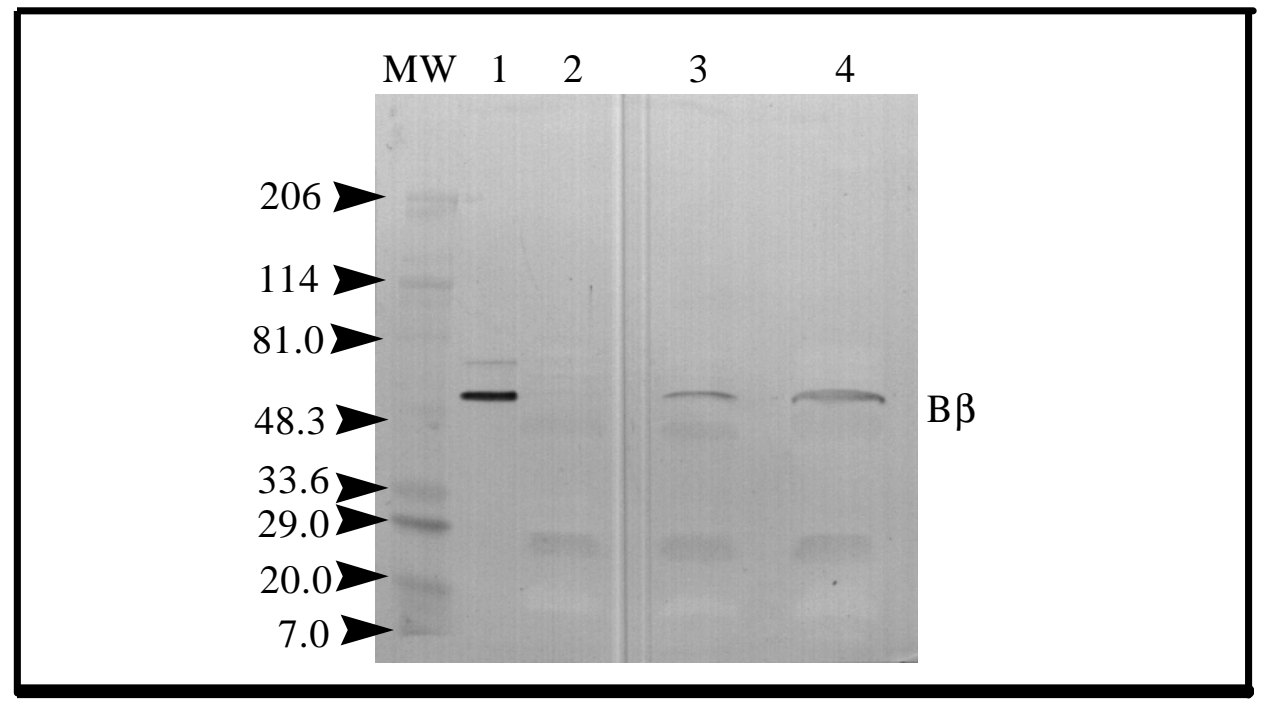

Figure 15. Western analysis of WAPFibB $\beta 1$ single chain mice.

Defatted mouse milk was separated on SDS-PAGE under reducing conditions and probed with a B $\beta$-chain polyclonal antibody. Sample lanes are: MW, molecular weight markers; 1, hfib 500 ng; lane 2, 1 $\mu 1$ control mouse milk; 3 , mouse 28 milk, $1 \mu \mathrm{l} ; 4$, mouse 28 milk, 3 $\mu 1 . \quad \mathrm{B} \beta=$ beta chain. 
Endo-H treatment, suggesting that the carbohydrate on the secreted $\mathrm{B} \beta$ subunit is complex in nature (data not shown).

\section{Discussion}

The secretion of completely assembled fibrinogen by the transgenic mammary gland has several requirements. First, expression constructs need to be developed that target each fibrinogen gene to the mammary gland and express the resulting mRNAs to a sufficient level for adequate subunit production. Second, cointegration of all three fibrinogen encoding constructs into a transcriptionally responsive chromosomal domain is needed. Also, the integration site must be germline transmissible and stable. Finally, these integrated constructs must be present and expressed in the correct ratio to limit secretion of unwanted fibrinogen precursors.

In this study, elements of the mWAP gene were used to express the cDNA coding portion of each fibrinogen chain during lactation to an order of magnitude of that secreted by the human liver. Production of mRNA by the transgenes was dependent upon the site of integration and to a lesser extent by the ratio of copies present. The transcripts produced by human liver are larger due to increases in size of their 5' and 3' untranslated regions (Rixon et al., 1983; Chung et al., 1983;1983b) and appear to migrate correctly in comparison to published observations (Roy et al., 1990). Variations in expression between lines and within a given line during different stages of lactation can be observed from Figure 6, indicating that the transgenes within a given locus are influenced by genetic elements flanking the integration site which has been observed by other investigators (Burdon et al., 1991; McKnight et al., 1995; Clark et al., 1994). Normally WAP message starts to accumulate at the end of gestation with a rapid linear increase after parturition to day 15 of lactation and then levels off (Hobbs et al., 1982). In several lines studied, deviations from normal expression were observed which include: low expression during early lactation and then an increase; high expression during early lactation then down regulation; high expression during first lactation then low expression during second lactation; and random expression during the course of lactation regardless of lactational status (see appendix tables $7,8,10,11,15$ ). In a study performed by Burdon et al. (1991) using a genomic mWAP construct, similar deviations from normal WAP gene expression were observed among transgenic lines. These alternative expression patterns are due to influences of chromatin flanking around the integration site and are not limited to mWAP promoting transgenes (Clark et al., 1994). Two variables

not controlled for in this study that may have a direct effect on the promoter used are the 
number of pups present within a litter and the pregnancy status of the mother. SchmittNey et al. (1992) demonstrated that regulation of a mammary gland transcription factor (Stat5) can be down regulated by the lack of suckling. However, the right posterior gland used in this study for RNA analysis from mice is usually suckled most frequently (personal observation). Also, the milk collected was from several teats and not one gland. Additionally, the effect of pregnancy on lactation could be a line specific factor affecting expression, as it has been noted that the WAP transgene can lose or gain hormone sensitivity depending on where it is integrated within the genome (Burdon et al., 1991; Shamay et al., 1992).

The number of transgenes within a given integration site did not correlate exactly with the levels of each mRNA produced. One possible reason for this observation is that the mWAP promoter does not transcribe each message at the same rate. In hepatocytes the three mRNAs are tightly regulated and expressed at relatively the same level with the amount of message fluctuating in response to: hepatocyte stimulating factor, interleukins, glucocorticoids and the level of individual subunits within the ER (Otto et al., 1987; Nesbitt and Fuller, 1991; Roy et al., 1994). Most of these influences are at the transcriptional level and should not regulate the constructs used in this study because of the different promoter element used and the lack of intronic sequences, which may harbor currently unknown regulatory elements. Another reason for the lack of message to DNA correlation may be the location of each transgene within the integration site. Since the distribution of constructs is random within the site of integration (Burdon et al., 1991) and the size of the transgene locus in the lines studied is greater than $55 \mathrm{kbp}$, it seems likely that elements flanking the locus could alter the overall ratio of message being produced by influencing only a portion of the transgenes. Prunkard et al. (1996), who used the oBLG promoter to express the genomic fibrinogen sequences, observed that the portion of subunits produced was consistent with the number of copies within the transgene locus, but no comment was made on the amount or ratio of the mRNAs present.

The relative level and ratio of mRNAs present in the mammary gland have a direct effect on the amount and composition of secreted fibrinogen and subunit complexes. In Line 37 mice that contain the highest levels of each mRNA, production of fully assembled fibrinogen was the highest. The imbalance favoring gamma in the mRNA ratio of this line resulted in the greatest variety of $\gamma$-chain secretion products. The most predominant product was the AG complex with lower amounts of $\gamma$-chain dimers and monomers. Line 21 also had a mRNA ratio favoring gamma, but produced this mRNA at a lower level, secreting only excess $\gamma$-chain as the AG complex. The relationship between mRNA ratio and subunit secretion is further strengthened by the observation that Line 10 with gamma 
mRNA limiting, did not secrete this complex. The AG complex has been secreted into the media of several different transfected cell types (Hartwig and Danishefsky, 1991; Binnie et al., 1993; Huang et al., 1996) and due to its apparent molecular weight may contain two $\gamma$-chains and one of $\mathrm{A} \alpha$.

In contrast to gamma chain behavior, the alpha chain was found in monomeric form in all lines studied. The secretion of the monomeric form in Line 37 is especially important because of the co-presence of monomeric gamma chain. This observation indicates that assembly of the A $\alpha$-chain into the AG complex is not absolute even in the presences of excessive amounts of $\gamma$-chain, suggesting a rate limitation at this point in chain assembly. The $A \alpha$-chain was also secreted in monomer form by the one monogenic line studied, and has been observed as a secretion product of transfected COS-1 cells (Hartwig and Danishefsky, 1991).

The secretion of the $\mathrm{B} \beta$-chain was limited to fully assembled fibrinogen in the trigenic lines studied and not found as a monomer or partial chain complex. In Lines 37 and 21, the $\mathrm{B} \beta$ subunit message was the lowest in the ratio. Therefore, it seems likely that most if not all of the polypeptide would be assembled in the full molecule, similar to the $\gamma$-chain in Line 10. However, the $\mathrm{B} \beta$ mRNA was not the lowest in Line 10 and did not form a chain complex, nor was it secreted in a monomer form. This suggest that the residual B $\beta$ chains were secreted at an undetectable level and/or degraded intracellularly. Niether hepatocytes nor transfected cells secrete the B $\beta$ subunit into media (Danishefsky et al., 1990; Roy et al., 1991; Hartwig and Danishefsky, 1991; Huang et al., 1993; Huang et al., 1996) and it has been observed that this chain is degraded intracellularly without expression of the two other chains (Danishefsky et al., 1990). Also, from these studies secretion of a $B \beta-\gamma$ complex was not detected, but was found intracellularly and may be a precursor for fibrinogen assembly (Huang et al., 1996). These results are in contrast to the observation that $\mathrm{B} \beta$-chain was secreted by the murine mammary gland. Since fibrinogen was secreted by mammary gland, the epithelia cells must contain the correct chaperons required for chain identification and assembly (Roy et al., 1990). Therefore, the retention and/or degradation mechanism found in other cell types is either nonexistent or present at a low level, thus allowing passage of the chain through the secretory system. One alterative possibility is that free $\mathrm{B} \beta$-chain becomes complexed with a naturally occurring milk protein, thereby preventing chain recognition by the retention/degradation pathway.

Interpretation of data from glycosylation studies performed on fibrinogen chains produced by the high expressing Line 37 suggest that both the $B \beta$ and $\gamma$ subunits and not the $A \alpha$ 
received a $\mathrm{N}$-linked core carbohydrate. The $\gamma$-chain was insensitive to Endo-H treatment but susceptible to PNGase, indicating that the saccharide chain attached is complex in composition. In contrast, the saccharide on the $\mathrm{B} \beta$-chain can be cleaved by Endo- $\mathrm{H}$, suggesting it is of the high mannose type. When the $\mathrm{B} \beta$-chain from monogenic mice was subjected to the same treatments, only PNGase resulted in band shifting. These observations indicate that the $\mathrm{B} \beta$ subunit can be recognized for processing of its high mannose core carbohydrate. Thus there was a preference for modifying the $\gamma$-chain saccharide in the glycosylation pathway when $\gamma$ subunits were produced at high levels. The preference for the glycosylation of the $\gamma$ subunits over B $\beta$ may be due to the presentation of the core mannose residues on assembled fibrinogen, where the residue on the $\gamma$ subunit is more accessible to processing enzymes.

In comparing this work to the published study by Prunkard et al. (1996) several observations appear to be in good agreement. The frequency of transgene transmission from founding animals to offspring varied in both studies with no transmission to greater than fifty percent being observed. This suggests that a significant percentage of founding animals are mosaic, where the transgenes were present in tail biopsies but not in germline tissue. The ratio of the transgenes present within an integration site was reported to be approximately equal, which is in good agreement with some of the mouse lines established in this study, but in contrast to other lines that had inbalanced ratios. In both studies, the ratio of fibrinogen subunits produced by a particular mouse line approximately followed the ratio of transgenes present within the integration site carried by that line. In contrast to the cell culture systems described in the introduction, the expression vectors used in both studies were able to drive subunit secretion to high levels in milk, approximately a thousand fold higher concentration than that found in conditioned cell culture media. Unfortunately, direct comparisons between both studies involving the glycosylation status of rhfib and the secretion of partial chain complexes into milk can not be made, as these observations were not reported by Prunkard et al. (1996).

In summary, there are several factors that should be considered when attempting to produce recombinant fibrinogen in the mammary gland of transgenic animals. One, promoter and coding sequences should be used to drive expression of each chain to high levels. In this study it has been shown that the $4.1 \mathrm{kbp}$ mWAP promoter is capable of expressing the fibrinogen cDNAs to produce sufficient mRNA levels for high protein secretion. This promoter is also capable of expressing genomic sequences to substantial levels in both mice and pigs, as in the case with Protein C (Drohan et al., 1994; Van Cott et al., 1997). Since genomic sequences are usually expressed to higher levels than 
cDNAs (McKnight et al., 1995; Clark et al., 1994), it would be beneficial to use both the 4.1 mWAP promoter and the genomic sequences for fibrinogen. However, there is a possibility of over expressing the transgenes resulting in inefficient maturation of saccharide residues, as with expressing rhfib in murine milk at a level of $700 \mu \mathrm{g} / \mathrm{ml}$. When trying to produce rhfib in transgenic livestock, the limitations of the mammary gland to glycosylate rhfib will have to be explored on a per species bases to identify the correct level of expression. The WAP6Fib constructs already developed may be capable of driving high level expression in livestock species, but currently the format is unproven in large animals. The most important factor to consider in trying to develop a production herd is the expression of all three chains in a fashion to optimize fibrinogen assembly. Currently, the exact ratio of chain expression necessary of optimization is unclear. Two undetermined factors influencing transgene design are the rate of translation of each mRNA and the rate of assembly of translation products by mammary epithelia. If the rate of translation is the same for each mRNA, then the transgenes should be present at equal copy numbers within the integration site. The best way to insure that all three constructs become integrated and at equal copy numbers, is to link the three together and microinject them as one construct. There are several technical difficulties with this strategy, but they can be overcome. The production of the construct would likely require several steps of DNA cloning and manipulation including restriction site additions and modifications. Also, the vector used in these manipulations would have to possess the ability to carry a large insert due to the projected size of at least $44 \mathrm{kbp}$ for the genomic coding construct or $22 \mathrm{kbp}$ for the cDNA coding one. Potential cloning vectors include: bacteria artificial chromosomes (BACs), yeast artificial chromosomes (YACs) and cosmids. These types of vectors are not as easy to work with as normally used plasmids. Another technical problem is that the concentration of DNA that can be microinjected is limited. Thus, the molar amount of the large construct would be reduced, potentially reducing the rate of integration. In conclusion, the path to producing high levels of correctly assembled recombinant human fibrinogen in the milk of transgenic livestock will be a long and difficult process, but necessary.

\section{References}

Alving BM, Weinstein MJ, Finlayson JS, Menitove JE, Frantantoni JC. (1995) Fibrin sealant: summary of a conference on characteristics and clinical uses. Transfusion 35:783-790.

Binnie CG, Hettasch JM, Strickland E, Lord ST. (1993) Characterization of purified recombinant fibrinogen: partial phosphorylation of fibrinopeptide A. Biochem. 32: 107- 
113.

Burdon T, Sankaran L, Wall R, Spencer M, Hennighausen L. (1991) Expression of a whey acidic protein transgene during mammary development. J. Biol. Chem. 266: 6909-6914.

Canseco RS, Sparks AET, Page RL, Russell CG, Johnson JL, Velander WH, Person RE, Drohan WN, Gwazdauskas FC. (1994) Gene transfer efficiency during gestation and the influence of co-transfer of non-manipulated embryos on ]production of transgenic mice. $\quad$ Transgenic Res. 3: 20-25.

Clark AJ, Bissinger P, Bullock DW, Damak S, Wallace R, Whitelaw CBA, Full Y. (1994) Chromosomal position effects and the modulation of transgene expression. Reprod. $\quad$ Fertil. Dev. 6: 589-598.

Chung DW, Que BG, Rixon MW, Mace M, Davie EW. (1983a) Characterization of complementary deoxyribonucleic acid and genomic deoxyribonucleic acid for the beta chain of human fibrinogen. Biochem. 22: 3244-3250.

Chung DW, Chan W, Davie EW. (1983b) Characterization of a complementary deoxyribonucleic acid coding for the gamma chain of human fibrinogen. Biochem. 22: $3250-3256$.

Cottingham I, McKee C, Temperley S, Garner I, Prunkard D, Lasser G, Bishop P, Foster D. Human fibrinogen from the milk of transgenic sheep. In: Tissue Sealants: Current Practice, Future Uses. Cambridge Healthtech Institute Newton Upper Fall, MA. May 51997.

Danishefsky K, Hartwig R, Banerjee D, Redman C. (1990) Intracellular fate of fibrinogen $\mathrm{B} \beta \quad$ chain expressed in COS cells. Biochem. Biophy. Acta 1048: 202-208.

Dodd RY, (1994) Infectious complications of blood transfusion. Hem. Oncol. Ann. 2:280287.

Doolittle RF. (1984) Fibrinogen and fibrin. Annu. Rev. Biochem. 53: 195-229.

Drohan WN, Zhang D, Paleyanda RK, Chang R, Wroble M, Velander W, Lubon H. (1994) Inefficient processing of human protein $\mathrm{C}$ in the mouse mammary gland. 
Transgenic Res. $\quad 3:, 355-364$.

Greco F, de Palma L, Spagnolo N, Rossi A, Specchia N, Gigante A. (1991) Fibrinantibiotic mixtures: an in vitro study assessing the possibility of using a biologic carrier for local drug delivery. J. Biomed. Mat. Res. 25:39-51.

Hartwig R, Danishefsky KJ. (1991) Studies on the assembly and secretion of fibrinogen. J. Biol. $\quad$ Chem. 266: 6578-6585.

Hobbs AA, Richards DA, Kessler DJ, Rosen JM. (1982) Complex hormonal regulation of rat casein gene expression. J. Biol. Chem. 257: 3598-3605.

Hogan B, Constantini F, Lacy E. (1986) Manipulating the Mouse Embryo: a Laboratory Manual. $\quad$ Cold Spring Harbor, NY: Cold Spring Harbor Laboratory Press.

Huang S, Cao Z, Chung DW, Davie EW. (1996) The role of $\beta \gamma$ and $\alpha \gamma$ complexes in the assembly of human fibrinogen. J. Biol. Chem. 271: 27942-27947.

Lasa C, Hollinger J, Drohan W, MacPhee M. (1996) Bone induction by demineralized bone powder and partially purified osteogenin using a fibrin-sealant carrier. In:

Surgical Adhesives and Sealants: Current Technology and Applications. Sierra D. and Saltz R.,eds. Technomic Publishing Co. Lancaster, PA.

Lubon H, Paleyanda RK, Velander WH et al. (1996) Blood proteins from transgenic animal bioreactors. Transfusion Medicine Reviews 10: 131-143.

MacPhee M, Campagna A, Kidd R, Best A, Drohan WN. (1996a) Fibrin sealant as a delivery vehicle for sustained and controlled release of chemotherapy agents. In: Surgical Adhesives and Sealants: Current Technology and Applications. Sierra D. and Saltz R., eds. Technomic Publishing Co. Lancaster, PA

MacPhee M, Nunez H, Hennings R, Campagna A, Grummon G, Harding S, Drohan W. (1996b) Sustained release in vitro and in vivo of antibiotics from fibrin sealant: In: Surgical Adhesives and Sealants: Current Technology and Applications. Sierra D. and Saltz R., eds. Technomic Publishing Co. Lancaster,PA.

McKnight RA, Wall RJ, Hennighausen L. (1995) Expression of genomic and cDNA transgenes after co-integration in transgenic mice. Transgenic Res. 4: 39-43 
Paleyanda, RK, Zhang D, Hennighausen L, McKnight RA, Lubon H. (1994) Regulation of human protein $\mathrm{C}$ gene expression by the mouse WAP promoter. Transgenic Res. 3: $335-343$.

Prunkard D, Cottingham, Garner I, Bruce S, Dalrymple M, Lasser G, Bishop P, Foster D. (1996) High-level expression of recombinant human fibrinogen in the milk of transgenic mice. $\quad$ Nature biotech. 14: 867-871

Rixon MW, Chan W, Davie EW, Chung DW. (1983) Characterization of a complementary deoxyribonucleic acid coding for the alpha chain of human fibrinogen. Biochem. 22: $\quad 3237-3244$.

Roy SN, Mukhopadhyay G, Redman C. (1990) Regulation of fibrinogen assembly. $J$. Biol. Chem. 265: 6389-6393.

Roy, S.N., Procyk, R., Kudryk, B.J., and Redman, C. (1991) Assembly and secretion of recombinant human fibrinogen. J. Biol. Chem. 266: 4758-4763.

Saiki RK, Walsh PS, Levenson CH, Erlich HA. (1989) Genetic analysis of amplified DNA with immobilized sequence-specific oligonucleotide probes. Proc. Natl. Acad. Sci. USA 86: 6230-6234.

Schmitt-Ney M., Happ B, Hofer P, Hynes N, Groner B. (1992) Mammary gland-specific nuclear factor activity is positively regulated by lactogenic hormones and negatively by milk stasis. Mol. Endo. 6: 1988-1997.

Shamay A, Pursel VG, Wilkinson E, Wall RJ, Hennighausen L. (1992) Expression of the whey acidic protein in transgenic pigs impairs mammary development. Transgenic Res. 1: $124-132$.

Van Cott KE, Lubon H, Russell CG, Butler SP, Gwazdauskas FC, Knight J, Drohan WN, Velander WH. (1997) Phenotypic and genotypic stablity of multiple lines of transgenic pigs expressing recombinant human protein C. Transgenic Res. 6:1-10

Velander, WH, Lubon H, Drohan WN. (1996) Transgenic livestock as Drug Factories. Sci Am. 276 (1): 70-74. 
Yu S, Sher B, Kudryk B, Redman CM. (1984) Fibrinogen precursors order of assembly of fibrinogen chains. J. Biol. Chem. 259: 10574-10581. 


\section{Chapter 4}

\section{Bibliography}

Alving BM, Weinstein MJ, Finlayson JS, Menitove JE, Frantantoni JC. (1995) Fibrin sealant: summary of a conference on characteristics and clinical uses. Transfusion 35:783-790.

Binnie CG, Hettasch JM, Strickland E, Lord ST. (1993) Characterization of purified recombinant fibrinogen: partial phosphorylation of fibrinopeptide A. Biochem. 32: 107113.

Burdon T, Sankaran L, Wall R, Spencer M, Hennighausen L. (1991) Expression of a whey acidic protein transgene during mammary development. J. Biol. Chem. 266: 6909-6914.

Campbell SM, Rosen JM, Hennighausen LG, Strech-Jurk U, Sippel AE. (1984) Comparison of the whey acidic protein genes of the rat and mouse. Nucl. Acids Res. 12: 9685-9687.

Canseco RS, Sparks AET, Page RL, Russell CG, Johnson JL, Velander WH, Person RE, Drohan WN, Gwazdauskas FC. (1994) Gene transfer efficiency during gestation and the influence of co-transfer of non-manipulated embryos on production of transgenic mice. Transgenic Res. 3: 20-25.

Carver A, Dalrymple M, Wright G, Cottom D, Reeves D, Gibson Y, Keenan J, Barrass J, Scott A, Colman A, Garner I. (1993) Transgenic livetock as bioreactors: stable expression on human alpha-1-antitrypsin by a flock of sheep. Bio/Technol. 11:12631270.

Clark AJ, Cowper A, Wallace R, Wright G, Simons JP. (1992) Rescuing transgene expression by co-integration. Bio.Technol. 10:1450-1454.

Clark AJ, Bissinger P, Bullock DW, Damak S, Wallace R, Whitelaw CBA, Full Y. (1994) Chromosomal position effects and the modulation of transgene expression. Reprod. $\quad$ Fertil. Dev. 6: 589-598.

Chung DW, Que BG, Rixon MW, Mace M, Davie EW. (1983a) Characterization of 
complementary deoxyribonucleic acid and genomic deoxyribonucleic acid for the beta chain of human fibrinogen. Biochem. 22: 3244-3250.

Chung DW, Chan W, Davie EW. (1983b) Characterization of a complementary deoxyribonucleic acid coding for the gamma chain of human fibrinogen. Biochem. 22: $3250-3256$.

Cottingham I, McKee C, Temperley S, Garner I, Prunkard D, Lasser G, Bishop P, Foster D. Human fibrinogen from the milk of transgenic sheep. In: Tissue Sealants: Current Practice, Future Uses. Cambridge Healthtech Institute Newton Upper Fall, MA. May 51997.

Dale TC, Krnacik MJ, Schmidhauser C, Yang CLQ, Bissell MJ, Rosen JM. (1992) Highlevel expression of the rat whey acidic protein gene is mediated by elements in the promoter and 3' untranslated region. Mol. Cel. Biol. 12: 905- 914.

Danishefsky K, Hartwig R, Banerjee D, Redman C. (1990) Intracellular fate of fibrinogen B $\beta \quad$ chain expressed in COS cells. Biochem. Biophy. Acta 1048: 202-208.

Dodd RY, (1994) Infectious complications of blood transfusion. Hem. Oncol. Ann. 2:280287.

Doolittle RF. (1984) Fibrinogen and fibrin. Annu. Rev. Biochem. 53: 195-229.

Doppler W, Villunger A, Jennewein P, Brduscha K, Groner B, Ball R. (1991)

Lactogenic hormone and cell type-specific control of the whey acidic protein gene promoter in transfected mouse cells. Mol. Endo. 5: 1624-1632.

Drohan WN, Zhang D, Paleyanda RK, Chang R, Wroble M, Velander W, Lubon H. (1994) Inefficient processing of human protein $\mathrm{C}$ in the mouse mammary gland. Transgenic Res. 3:, 355-364.

Greco F, de Palma L, Spagnolo N, Rossi A, Specchia N, Gigante A. (1991) Fibrin antibiotic mixtures: an in vitro study assessing the possibility of using a biologic carrier for local drug delivery. J. Biomed. Mat. Res. 25:39-51.

Hartwig R, Danishefsky KJ. (1991) Studies on the assembly and secretion of fibrinogen. J. Biol. Chem. 266: 6578-6585. 
Hennighausen LG, Sippel AE. (1982) Mouse whey acidic protein is a novel memberof the family of 'four-disulfide core' proteins. Nucl. Acids Res. 10: 2677-2684.

Hobbs AA, Richards DA, Kessler DJ, Rosen JM. (1982) Complex hormonal regulation of rat casein gene expression. J. Biol. Chem. 257: 3598-3605.

Hogan B, Constantini F, Lacy E. (1986) Manipulating the Mouse Embryo: a Laboratory Manual. Cold Spring Harbor, NY: Cold Spring Harbor Laboratory Press.

Huang S, Mulvihill ER, Farrell DH, Chung DW, Davie EW. (1993) Biosynthesis of human fibrinogen. J. Biol. Chem. 268: 4919-4926.

Huang S, Cao Z, Chung DW, Davie EW. (1996) The role of $\beta \gamma$ and $\alpha \gamma$ complexes in the assembly of human fibrinogen. J. Biol. Chem. 271: 27942-27947.

Jhappan C, Geiser AG, Kordon EC, Bagheri D, Hennighausen L, Roberts AB, Smith GH, Merlino G. (1993) Targeting expression of a transforming growth factor $\beta 1$ transgene to the pregnant mammary gland inhibits alveolar development and lactation. EMBO J. 12: $1835-1845$.

Lasa C, Hollinger J, Drohan W, MacPhee M. (1996) Bone induction by demineralized bone powder and partially purified osteogenin using a fibrin-sealant carrier. In: Surgical Adhesives and Sealants: Current Technology and Applications.

Sierra D. and Saltz R.,eds. Technomic Publishing Co. Lancaster, PA.

Lubon $\mathrm{H}$ and Hennighausen L. (1987) Nuclear proteins from lactating mammary glands bind to the promoter of a milk protein gene. Nucl. Acids Res. 15: 2103-2121.

Lubon H, Paleyanda RK, Velander WH et al. (1996) Blood proteins from transgenic animal bioreactors. Transfusion Medicine Reviews 10: 131-143.

MacPhee M, Campagna A, Kidd R, Best A, Drohan WN. (1996a) Fibrin sealant as a elivery vehicle for sustained and controlled release of chemotherapy agents. In: Surgical Adhesives and Sealants: Current Technology and Applications. Sierra D. and Saltz R., eds. Technomic Publishing Co. Lancaster, PA

MacPhee M, Nunez H, Hennings R, Campagna A, Grummon G, Harding S, Drohan W. 
(1996b) Sustained release in vitro and in vivo of antibiotics from fibrin sealant: In: Surgical Adhesives and Sealants: Current Technology and Applications. Sierra D. and Saltz R., eds. Technomic Publishing Co. Lancaster,PA.

McClenaghan M, Springbett A, Wallace RM, Wilde CJ, Clark AJ. (1995) Secretory proteins compete for production in the mammary gland of transgenic mice.

Biochem. J. 310:637-641.

McKnight RA, Wall RJ, Hennighausen L. (1995) Expression of genomic and cDNA transgenes after co-integration in transgenic mice. Transgenic Res. 4: 39-43.

McKnight RA, Spencer M, Dittmer J, Brandy JN, Wall RJ, Hennighausen L. (1995a) An Ets site in the whey acidic protein gene promoter mediates transcriptional activation in the mammary gland of pregnant mice but is dispensable during lactation. Mol. Endo. 9: 717- 724.

Mink S, Hartig E, Jennewein P, Doppler W, Cato ACB. (1992) A mammary cell-specific enhancer in mouse mammary tumor virus DNA is composed of multiple regulatory elements including binding sites for CTF/NFI and novel transcription factor, mammary cell-activating factor. Mol. Cel. Biol. 12: 4906-4918.

Morcol T, Akers RM, Johnson J.L et al. (1994) The porcine mammary gland as a bioreactor for complex proteins. Ann. N. Y. Acad. Sci. 721:218-233.

Nesbitt JE and Fuller GM. (1991) Transcription and translation are required for fibrinogen mRNA degradation in hepatocytes. Biochim Biophy Acta. 1089: 88-94.

Otto JM, Grenett HE, Fuller GM. (1987) The coordinated regulation of fibrinogen gene transcription by hepatocyte-stmulating factor and dexamethasone. J. Cell Biol.

105: $1067-1072$.

Paleyanda R, Young J, Velander, W et al. (1991) The expression of therapeutic proteins in transgenic animals. In Hoyer LW and Drohan WN, eds., Recombinant Technology in Hemostasis and Thrombosis.New York: Plenum Press. 197-209.

Paleyanda, RK, Zhang D, Hennighausen L, McKnight RA, Lubon H. (1994) Regulation of human protein $\mathrm{C}$ gene expression by the mouse WAP promoter. Transgenic Res. 3: $335-343$. 
Pittus CW, Hennighausen L, Lee E, Westphal H, Nicols E, Vitale J, Gordon K. (1988) A milk protein gene promoter directs the expression of human tissue plasminogen activator cDNA to the mammary gland in transgenic mice. Proc. Natl. Acad. Sci. 85: 5874-78.

Prunkard D, Cottingham, Garner I, Bruce S, Dalrymple M, Lasser G, Bishop P, Foster D. (1996) High-level expression of recombinant human fibrinogen in the milk of transgenic mice. Nature Biotech. 14: 867-871.

Reddy VB, Vitale JA, Wei C, Montoya-Zavala M, Stice SL, Balise J, Robl JM. (1991) Expression of human growth hormone in the milk of transgenic mice. Animal Biotech. 2: 15-29.

Rixon MW, Chan W, Davie EW, Chung DW. (1983) Characterization of a complementary deoxyribonucleic acid coding for the alpha chain of human fibrinogen. Biochem. 22: 3237-3244.

Roy SN, Mukhopadhyay G, Redman C. (1990) Regulation of fibrinogen assembly. $J$. Biol. Chem. 265: 6389-6393.

Roy SN, Procyk R, Kudryk BJ, Redman C. (1991) Assembly and secretion of recombinant human fibrinogen. J. Biol. Chem. 266: 4758-4763.

Roy SN, Overton O, Redman C. (1994) Overexpression of any fibrinogen chain by HepG2 cells specifically elevates the expression of the other two chains. $J$. Biol. Chem. 269: 691-695.

Roy SN, Kudryk B, Redman CM. (1995) Secretion of biologically active recombinant fibrinogen by yeast. J. Biol. Chem. 270: 23761-23767.

Russell, C.G. (1994) Improvement of expression of recombinant human protein C in the milk of transgenic animals using a novel transgene construct. (Ph.D

Dissertation) Virginia Polytechnic Insititute \& S.U. : 1-146.

Saiki RK, Walsh PS, Levenson CH, Erlich HA. (1989) Genetic analysis of amplified DNA with immobilized sequence-specific oligonucleotide probes. Proc. Natl. Acad. Sci. USA 86: 6230-6234. 
Schmitt-Ney M., Happ B, Hofer P, Hynes N, Groner B. (1992) Mammary gland-specific nuclear factor activity is positively regulated by lactogenic hormones and negatively by milk stasis. Mol. Endo. 6: 1988-1997.

Shamay A, Pursel VG, Wilkinson E, Wall RJ, Hennighausen L. (1992) Expression of the whey acidic protein in transgenic pigs impairs mammary development. Transgenic Res. 1: $124-132$.

Toman D, Platenburg G, Sakai N, de Wit I, Plantenburg E, Samuel C, Chang R., Dekker A, Pieper F, Berg R. (1997) Production of human type I procollagen Heterotrimeric molecules in transgenic mouse milk. International Business Communications, Southborough, MA. Feb 5.

Tomasetto C, Wolf C, Rio M, Mehtali M, LeMeur M, Gerlinger P, Chambon P, Lathe R. (1989) Breast cancer protein PS2 synthesis in mammary gland of transgenic mice into milk. $\quad$ Mol. Endocrinol. 3: 1579-1584.

Van Cott KE, Lubon H, Russell CG, Butler SP, Gwazdauskas FC, Knight J, Drohan WN, Velander WH. (1997) Phenotypic and genotypic stablity of multiple lines of transgenic pigs expressing recombinant human protein C. Transgenic Res. 6:1-10

Velander WH, Morcol T, Clark DB et al. (1990) Technological challenges for large-scale purification of Protein C, In Bruley, D.F. and Drohan, W.N., eds., Protein $C$ and Related Anticoagulants. The Woodlands, Texas: Portfolio Publishing 10-27.

Velander WH, Page RL, Morcol T, Russell CG, Canseco R., Young JM, Drohan WN, Gwazdauskas FC, Wilkins TD, Johnson JL. (1992a) Production of biologically active human protein $\mathrm{C}$ in the milk of transgenic mice. Annu. N.Y. Acad. Sci. 665: 391403.

Velander WH, Johnson JL, Page RL et al. (1992b) High-level expression of a heterologous protein in the milk of transgenic swine using the cDNA encoding human protein C. Proc. $\quad$ Natl. Acad. Sci. USA, 89: 12003-12007.

Velander, WH, Lubon H, Drohan WN. (1996) Transgenic livestock as Drug Factories. Sci. Am. 276 (1):70-74. 
Watson CJ, Gordon KE, Robertson M, and Clark AJ. (1991) Interaction of DNA binding proteins with a milk protein gene promoter in vitro: identification of a mammary gland- specific factor. Nucl. Acids Res. 19: 6603-6610.

Welte T, Phlipp S, Cairns C, Gustafsson JA, Doppler W. (1993) Glucocorticoid receptor binding sites in the promoter region of milk protein genes. J. Steroid Biochem. Mol. Biol. 47: 75- 81 .

Yu S, Sher B, Kudryk B, Redman CM. (1984) Fibrinogen precursors order of assembly of fibrinogen chains. J. Biol. Chem. 259: 10574-10581. 
Chapter 5

Appendix 
Table 6. Summary of transgene transmission from founder animals.

\begin{tabular}{|c|c|c|}
\hline Mouse I.D & $\begin{array}{l}\text { (positive) / total \# } \\
\text { animals }\end{array}$ & $\begin{array}{l}\text { Transmission } \\
\text { Frequency }\end{array}$ \\
\hline WAP6FibT.C. 2 & (3) / 23 & $13 \%$ \\
\hline WAP6FibT.C 10 & (7) / 32 & $21 \%$ \\
\hline WAP6FibT.C. 18 & $(13) / 32$ & $40 \%$ \\
\hline WAP6FibT.C. 21 & (6) / 21 & $29 \%$ \\
\hline WAP6FibT.C. 30 & (5) / 20 & $25 \%$ \\
\hline WAP6FibT.C. 37 & $(5) / 17$ & $29 \%$ \\
\hline WAP6FibA $\alpha 114$ & (6) / 14 & $43 \%$ \\
\hline WAP6FibA $\alpha 126$ & (11) / 29 & $37 \%$ \\
\hline WAP6FibA $\alpha 127$ & $(10) / 20$ & $50 \%$ \\
\hline WAP6FibA $\alpha 133$ & (6) / 14 & $43 \%$ \\
\hline WAP6FibA $\alpha 143$ & (5) / 9 & $55 \%$ \\
\hline WAP6FibA $\alpha 145$ & (4) / 20 & $20 \%$ \\
\hline WAP6FibB $\beta 18$ & (9) / 13 & $69 \%$ \\
\hline WAP6FibB $\beta 114$ & $(7) / 28$ & $25 \%$ \\
\hline WAP6FibB $\beta 116$ & (2) / 7 & $28 \%$ \\
\hline WAP6FibB $\beta 121$ & (7) / 13 & $54 \%$ \\
\hline WAP6FibB $\beta 125$ & (6) / 14 & $43 \%$ \\
\hline WAP6FibB $\beta 128$ & (4) / 8 & $50 \%$ \\
\hline WAP6Fib $\gamma 11$ & (4) / 20 & $20 \%$ \\
\hline WAP6Fib $\gamma 16$ & (7) / 17 & $41 \%$ \\
\hline
\end{tabular}


Table 7. Data set for WAP6Fib $\alpha \beta \gamma$ Line 10 mice.

\begin{tabular}{||l|c|c|c|c|c|c||}
\hline \multicolumn{1}{|c|}{ Mouse } & $\begin{array}{c}\text { Day of } \\
\text { lactation }\end{array}$ & Lactation & \multicolumn{3}{|c|}{$\begin{array}{c}\text { Human Liver ng total RNA per } \\
10 \mu \mathrm{g} \text { mammary total RNA }\end{array}$} & $\begin{array}{c}\text { rhfib } \\
\mu \mathrm{g} / \mathrm{ml} \text { in } \\
\text { milk }\end{array}$ \\
\hline $10-27-5-6$ & 5 & $1 \mathrm{st}$ & 41.9 & 370.6 & 153 & $10^{*}$ \\
\hline $10-27-5-5$ & 5 & $1 \mathrm{st}$ & 129.3 & 171.6 & 26.9 & 20 \\
\hline $10-13$ & 5 & $2 \mathrm{nd}$ & 3502 & 2656 & 879 & $150-450$ \\
\hline $10-27-5-1$ & 10 & 1 st & 134.7 & 107 & 185 & 100 \\
\hline $10-27-1-1$ & 10 & 1 st & 262.7 & 209 & 73 & $10^{*}$ \\
\hline $10-23$ & 11 & $2 \mathrm{md}$ & 1518.5 & 1285 & 129 & 40 \\
\hline $10-28$ & 15 & 2nd & 2242 & 1844 & 1514 & 450 \\
\hline $10-28-2$ & 15 & 2nd & 97.8 & 74.8 & 90 & $10^{*}$ \\
\hline $10-27-1$ & 15 & 3rd & 270.5 & 368 & 344 & 60 \\
\hline
\end{tabular}

* pooled samples 
Table 8. Data set for WAP6Fib $\alpha \beta \gamma$ line 21 mice.

\begin{tabular}{|c|c|c|c|c|c|c|}
\hline \multirow{3}{*}{$\begin{array}{l}\text { Mouse } \\
21-8-22\end{array}$} & \multirow{3}{*}{$\begin{array}{l}\text { Day of } \\
\text { lactation }\end{array}$} & \multirow{3}{*}{$\begin{array}{c}\text { Lactation } \\
1 \mathrm{st}\end{array}$} & \multicolumn{3}{|c|}{$\begin{array}{l}\text { Human Liver ng total RNA per } \\
10 \mu \mathrm{g} \text { mammary total RNA }\end{array}$} & \multirow{3}{*}{$\begin{array}{c}\text { rhfib } \\
\mu \mathrm{g} / \mathrm{ml} \text { in } \\
\text { milk } \\
25^{*}\end{array}$} \\
\hline & & & \multicolumn{3}{|l|}{$\begin{array}{l}\alpha \text { mRNA } \\
\text { mRNA }\end{array}$} & \\
\hline & & & 99.3 & 28.5 & 342.1 & \\
\hline $21-8-20$ & 5 & $1 \mathrm{st}$ & 0 & 0 & 33.6 & $25^{*}$ \\
\hline $21-2$ & 5 & $1 \mathrm{st}$ & & & & 0 \\
\hline $21-18$ & 5 & $1 \mathrm{st}$ & & & & 0 \\
\hline $21-2-2$ & 5 & 2nd & 25.9 & 39.2 & 58.8 & 0 \\
\hline $21-3$ & 10 & $1 \mathrm{st}$ & & & & 0 \\
\hline $21-3-3$ & 10 & $1 \mathrm{st}$ & 0 & 0 & 43.8 & $65 * *$ \\
\hline $21-3-2$ & 10 & $1 \mathrm{st}$ & 0 & 0 & 17.8 & $65 * *$ \\
\hline $21-2-1$ & 10 & $1 \mathrm{st}$ & 0 & 0 & 0 & $25 *$ \\
\hline $21-3-4$ & 10 & 2nd & 143.9 & 69 & 486 & 20 \\
\hline $21-3$ & 15 & $1 \mathrm{st}$ & & & & 125 \\
\hline $21-14$ & 16 & $1 \mathrm{st}$ & 215 & 22.7 & 487 & 175 \\
\hline $21-18$ & 16 & $1 \mathrm{st}$ & 0 & 37.5 & 134 & $65 * *$ \\
\hline $21-2$ & 16 & 2nd & 0 & 0 & 0 & 10 \\
\hline
\end{tabular}

* pooled samples, ** pooled samples 
Table 9. Data set for WAP6Fib $\alpha \beta \gamma$ Line 37 mice.

\begin{tabular}{||l|c|c|c|c|c|c||}
\hline Mouse & $\begin{array}{c}\text { Day of } \\
\text { lactation }\end{array}$ & Lactation & \multicolumn{3}{|c|}{$\begin{array}{r}\text { Human Liver ng total RNA per } \\
10 \mu \mathrm{g} \text { total mammary RNA }\end{array}$} & $\begin{array}{c}\text { rhfib } \\
\mu \mathrm{g} / \mathrm{ml} \text { in } \\
\text { milk }\end{array}$ \\
\hline $37-4$ & 5 & $1 \mathrm{st}$ & & & & 660 \\
\hline $37-21$ & 5 & $1 \mathrm{st}$ & 10360 & 2889 & 4920 & 170 \\
\hline $37-7$ & 10 & $2 \mathrm{nd}$ & & & & 370 \\
\hline $37-7$ & 10 & $3 \mathrm{rd}$ & 11326 & 7020 & 23262 & 590 \\
\hline $37-12$ & 15 & $1 \mathrm{st}$ & 758 & 558 & 2160 & $15^{*}$ \\
\hline
\end{tabular}

*clotted sample 
Table 10. Data set for WAP6FibA $\alpha$ Line 43 mice.

\begin{tabular}{||c|c|c|c|c||}
\hline Mouse & $\begin{array}{c}\text { Day of } \\
\text { lactation }\end{array}$ & Lactation & $\begin{array}{c}\text { Human Liver ng total RNA per 10 } \\
\mu \mathrm{g} \text { total mammary RNA } \\
\text { A } \alpha \text { mRNA }\end{array}$ & $\begin{array}{c}\text { A } \alpha \text { chain } \\
\mu \mathrm{g} / \mathrm{ml} \text { in } \\
\text { milk }\end{array}$ \\
\hline $43-6$ & 5 & $1 \mathrm{st}$ & 30.2 & \\
\hline $43-2$ & 10 & $1 \mathrm{st}$ & 43.6 & 150 \\
\hline $43-8$ & 13 & $1 \mathrm{st}$ & & 150 \\
\hline $43-8$ & 15 & $1 \mathrm{st}$ & 168.4 & \\
\hline
\end{tabular}


Table 11. Data set for WAP6FibB $\beta 1$ Line 8 mice.

\begin{tabular}{||l|c|c|c|c||}
\hline Mouse & $\begin{array}{c}\text { Day of } \\
\text { lactation }\end{array}$ & Lactation & $\begin{array}{c}\text { Human Liver ng total RNA per } \\
10 \mu \mathrm{g} \text { total mammary RNA } \\
\text { B } \beta \text { mRNA }\end{array}$ & $\begin{array}{c}\text { BB chain } \\
\mu \mathrm{g} / \mathrm{ml} \text { in } \\
\text { milk }\end{array}$ \\
\hline $8-1$ & 5 & $1 \mathrm{st}$ & 423.1 & $50^{*}$ \\
\hline $8-4$ & 10 & $1 \mathrm{st}$ & 1890 & $50^{*}$ \\
\hline $8-2$ & 10 & $1 \mathrm{st}$ & & 30 \\
\hline $8-10$ & 10 & $1 \mathrm{st}$ & 1872 & $20^{* *}$ \\
\hline $8-9$ & 10 & $2 \mathrm{nd}$ & 1708 & $20^{* *}$ \\
\hline $8-2$ & 15 & $1 \mathrm{st}$ & 0 & $50^{*}$ \\
\hline $8-3$ & 15 & $3 \mathrm{rd}$ & 27.7 & $20^{* *}$ \\
\hline
\end{tabular}

* pooled samples, ** pooled samples 
Table 12. Data set for WAP6FibB $\beta 1$ Line 14 mice.

\begin{tabular}{|c|c|c|c|c|}
\hline $\begin{array}{c}\text { Mouse } \\
\text { I.D. }\end{array}$ & $\begin{array}{c}\text { Day of } \\
\text { lactation }\end{array}$ & Lactation & $\begin{array}{l}\text { Human Liver ng total RNA per } \\
10 \mu \mathrm{g} \text { total mammary RNA } \\
\text { B } \beta \text { mRNA }\end{array}$ & $\begin{array}{l}\text { BB chain } \\
\mu \mathrm{g} / \mathrm{ml} \text { in } \\
\text { milk }\end{array}$ \\
\hline $14-6$ & 5 & $1 \mathrm{st}$ & & 0 \\
\hline $14-7$ & 6 & $1 \mathrm{st}$ & & 40 \\
\hline $14-7$ & 10 & $1 \mathrm{st}$ & & 0 \\
\hline $14-7-3$ & 10 & $1 \mathrm{st}$ & 108.8 & $0 *$ \\
\hline $14-6$ & 15 & $1 \mathrm{st}$ & & 0 \\
\hline $14-6$ & 16 & 2nd & 30.2 & $0 *$ \\
\hline $14-7$ & 15 & 2nd & 27.1 & $0 *$ \\
\hline
\end{tabular}

* pooled samples 
Table 13. Data set for WAP6FibB $\beta 1$ Line 21 mice.

\begin{tabular}{||l|c|c|c|c||}
\hline Mouse & $\begin{array}{c}\text { Day of } \\
\text { lactation }\end{array}$ & Lactation & $\begin{array}{c}\text { Human Liver ng total RNA per } \\
10 \mu \mathrm{g} \text { total mammary RNA } \\
\text { B } \beta \text { mRNA }\end{array}$ & $\begin{array}{c}\text { BB chain } \\
\mu \mathrm{g} / \mathrm{ml} \text { in } \\
\text { milk }\end{array}$ \\
\hline $21-15$ & 5 & $1 \mathrm{st}$ & 44.4 & $0^{*}$ \\
\hline $21-6$ & 4 & $1 \mathrm{st}$ & & 0 \\
\hline $21-17$ & 5 & $1 \mathrm{st}$ & & $0^{*}$ \\
\hline $21-16$ & 9 & $1 \mathrm{st}$ & 340 & $0^{*}$ \\
\hline $21-1$ & 15 & $2 \mathrm{nd}$ & 93.5 & $0 * *$ \\
\hline $21-5$ & 15 & 2nd & & $0 * * *$ \\
\hline $21-6$ & 15 & 2nd & & 0 \\
\hline
\end{tabular}

* pooled samples, ** pooled samples 
Table 14. Data set for WAP6FibB $\beta 1$ Line 25 mice.

\begin{tabular}{|c|c|c|c|c|}
\hline Mouse & $\begin{array}{c}\text { Day of } \\
\text { lactation }\end{array}$ & Lactation & $\begin{array}{l}\text { Human Liver ng total RNA per } \\
10 \mu \mathrm{g} \text { total mammary RNA } \\
\mathrm{B} \beta \text { mRNA }\end{array}$ & $\begin{array}{l}\text { BB chain } \\
\mu \mathrm{g} / \mathrm{ml} \text { in } \\
\text { milk }\end{array}$ \\
\hline $25-8$ & 5 & $1 \mathrm{st}$ & & 0 \\
\hline $25-9$ & 5 & $1 \mathrm{st}$ & & 0 \\
\hline $25-8-3$ & 5 & $1 \mathrm{st}$ & 157.9 & $35^{*}$ \\
\hline $25-8-5$ & 5 & $1 \mathrm{st}$ & & $35^{*}$ \\
\hline $25-2$ & 10 & $1 \mathrm{st}$ & & 0 \\
\hline $25-8-2$ & 10 & $1 \mathrm{st}$ & 116.4 & $40 * *$ \\
\hline $25-11$ & 10 & $1 \mathrm{st}$ & & 45 \\
\hline $25-9$ & 10 & $1 \mathrm{st}$ & & 0 \\
\hline $25-8$ & 10 & 2nd & & $35^{*}$ \\
\hline $25-5$ & 10 & $3 \mathrm{rd}$ & & $35^{*}$ \\
\hline $25-11-2$ & 15 & $1 \mathrm{st}$ & & $40 * *$ \\
\hline $25-5$ & 16 & $1 \mathrm{st}$ & & 0 \\
\hline $25-9$ & 15 & $2 \mathrm{nd}$ & 39.0 & $40 * *$ \\
\hline $25-11$ & 15 & $3 r d$ & & $40 * *$ \\
\hline
\end{tabular}

*pooled samples, ** pooled samples 
Table 15. Data set for WAP6FibB $\beta 1$ Line 28 mice.

\begin{tabular}{||l|c|c|c|c||}
\hline Mouse & $\begin{array}{c}\text { Day of } \\
\text { lactation }\end{array}$ & Lactation & $\begin{array}{c}\text { Human Liver ng total RNA per } \\
10 \mu \mathrm{g} \text { total mammary RNA } \\
\text { B } \beta \text { mRNA }\end{array}$ & $\begin{array}{c}\text { BB chain } \\
\mu \mathrm{g} / \mathrm{ml} \text { in } \\
\text { milk }\end{array}$ \\
\hline $28-1$ & 5 & $1 \mathrm{st}$ & & 10 \\
\hline $28-1-8$ & 7 & $1 \mathrm{st}$ & 134.7 & 0 \\
\hline $28-1-6$ & 11 & $1 \mathrm{st}$ & 624 & 100 \\
\hline $28-1-7$ & 15 & $1 \mathrm{st}$ & 1835 & 100 \\
\hline
\end{tabular}


Table 16. Data set for WAP6Fib $\gamma 1$ Line 1 and Line 6 mice.

\begin{tabular}{|c|c|c|c|c|}
\hline $\begin{array}{c}\text { Mouse } \\
\text { I.D. }\end{array}$ & $\begin{array}{l}\text { Day of } \\
\text { lactation }\end{array}$ & Lactation & $\begin{array}{c}\text { Human Liver ng total RNA per } \\
10 \mu \mathrm{g} \text { total mammary RNA } \\
\gamma \text { mRNA }\end{array}$ & $\begin{array}{l}\gamma \text { chain } \\
\mu \mathrm{g} / \mathrm{ml} \text { in } \\
\text { milk }\end{array}$ \\
\hline $1-3-12$ & 5 & $1 \mathrm{st}$ & 91.5 & 0 \\
\hline $1-3-5$ & 10 & $1 \mathrm{st}$ & 89.3 & 0 \\
\hline $1-1-8$ & 10 & 2nd & & $0 *$ \\
\hline $1-3-6$ & 15 & 2nd & 329.2 & 0 \\
\hline $1-1-12$ & 15 & 2nd & & $0 *$ \\
\hline $6-3$ & 10 & $1 \mathrm{st}$ & & 0 \\
\hline $6-1$ & 10 & 2nd & & $0 * *$ \\
\hline $6-3$ & 10 & $3 \mathrm{rd}$ & 39.4 & $0 * *$ \\
\hline $6-6$ & 15 & 2nd & 24.3 & $0 * *$ \\
\hline $6-8$ & 15 & 2nd & & $0 * *$ \\
\hline
\end{tabular}

* pooled samples, ** pooled samples 
Vita

Stephen Philip Butler received a B.S. degree in Biochemistry at Virginia Polytechnic Institute \& S.U. in 1992.

Publications:

Stephen P. Butler, Kevin E.Van Cott, Anuradha Subrumanian, Francis C. Gwazdauskas, and William H. Velander. Current Progress in the Production of Recombinant Human Fibrinogen in the Milk of Transgenic Animals. Hemostasis and Thrombosis (in press).

Kevin E. Van Cott, Henryk Lubon, Christopher G. Russel, Stephen P. Butler, F.C. Gwazdauskas, James Knight, William N. Drohan, and William H. Velander. (1997) Phenotypic and Genotypic Stability of Multiple Lines of Transgenic Pigs Expressing Recombinant Human Protein C. Transgenic Res. 6:1-10.

Raymond L. Page, Stephen P. Butler, Anuradha Subramanian, Francis C. Gwazdauskas, John L. Johnson and William H. Velander. (1995) Transgenesis in mice by cytoplasmic injection of polylysine/DNA mixtures. Transgenic Res. 4:353-360. 